\title{
ANTAGONISMO DE CULTURAS LÁTICAS ASSOCIADAS COM CANA-DE-AÇÚCAR SOBRE Gluconacetobacter diazotrophicus
}

\author{
JANEEYRE FERREIRA MACIEL \\ Engenheiro de Alimentos
}

Orientador: Prof. Dr. JORGE HORII

\begin{abstract}
Tese apresentada à Escola Superior de Agricultura "Luiz de Queiroz", Universidade de São Paulo, para obtenção do título de Doutor em Agronomia, Área de concentração: Microbiologia Agrícola.
\end{abstract}

\section{PIRACICABA}

Estado de São Paulo - Brasil

Junho - 2001 


\section{ERRATA}

Janeeyre Ferreira Maciel. Antagonismo de culturas láticas associadas com cana-deaçúcar sobre Gluconabacter diazotrophicus.

\begin{tabular}{|c|c|c|c|c|}
\hline p. & item & linha & onde se lê & ia-se \\
\hline $\mathrm{v}$ & 3.3 & segunda & $\begin{array}{l}\ldots \text { na água da bainha } \\
\text { das folhas }\end{array}$ & $\begin{array}{l}\text {... na água da bainha das folhas de } \\
\text { cana-de-açúcar }\end{array}$ \\
\hline vii & 1 e 2 & terceira & $\begin{array}{l}\text {... coletada na cidade } \\
\text { de Ivaí-PR }\end{array}$ & $\begin{array}{l}\text {... coletada no município de Ivaí- } \\
\text { PR }\end{array}$ \\
\hline vii & 3 & segunda & $\begin{array}{l}\text { direto, para os iso- } \\
\text { lados ... }\end{array}$ & deferido, para os isolados ... \\
\hline vii & 4 & segunda & $\begin{array}{l}\text { deferido, para os iso- } \\
\text { lados ... }\end{array}$ & direto, para os isolados ... \\
\hline $\begin{array}{l}\text { ix e } \\
x\end{array}$ & $\begin{array}{l}1,3,4 \\
5 \text { e } 6\end{array}$ & segunda & ...coletadas nas cidades & ... coletadas nos municípios \\
\hline ix & 2 & $\begin{array}{l}\text { primeira e } \\
\text { segunda }\end{array}$ & $\begin{array}{l}\text { coletadas nas } \\
\text { cidades de } \ldots\end{array}$ & ... coletadas nos municípios de ... \\
\hline $\mathrm{x}$ & $\begin{array}{l}7,8 \mathrm{e} \\
9\end{array}$ & segunda & $\begin{array}{l}\text {... coletadas na cidade } \\
\text { de } \ldots\end{array}$ & $\begin{array}{l}\text {... coletadas no município } \\
\text { de ... }\end{array}$ \\
\hline $\mathrm{x}$ & 10 & $\begin{array}{l}\text { primeira, } \\
\text { segunda e } \\
\text { terceira }\end{array}$ & $\begin{array}{l}\text { Zonas de inibição ... } \\
\text { de Ivaí-PR }\end{array}$ & $\begin{array}{l}\text { Resultados estatísticos das conta- } \\
\text { gens de bactérias totais e de } \\
\text { bactérias láticas (UFC/mL) nas } \\
\text { amostras de água da bainha das } \\
\text { folhas de cana-de-açúcar, coleta- } \\
\text { das no município de Itapetinga- } \\
\text { BA }\end{array}$ \\
\hline$x$ & 11 & terceira & $\begin{array}{l}\ldots \text { coletadas na } \\
\text { cidade de Piracicaba- } \\
\text { SP }\end{array}$ & $\begin{array}{l}\text {... coletadas no município de Ivaí- } \\
\text { PR }\end{array}$ \\
\hline$x$ & 12 & terceira & $\begin{array}{l}\text {... coletadas na cidade } \\
\text { de Itapetinga-BA }\end{array}$ & $\begin{array}{l}\text {... coletadas no município de } \\
\text { Piracicaba-SP }\end{array}$ \\
\hline
\end{tabular}




$\begin{array}{llll}\text { p. } & \text { item } & \text { linha } & \text { onde se lê } \\ \text { xi } & 13 & \begin{array}{l}\text { primeira, } \\ \text { segunda } \\ \text { terceira }\end{array} & \begin{array}{l}\text { Resultados estatísticos } \\ \text { das contagens... } \\ \text { de Itapetinga-BA }\end{array}\end{array}$

xii

xiv

14

2.5 terceira $\mathrm{Kg}$

$14 \quad 2.5$

14

2.5 décima

oitava

terceira

$$
\left.10^{5} \mathrm{UFC} / \mathrm{g}\right) \text {, quando } \ldots
$$

... (in the order of $10^{5}$ UFC/g), when ...

$\mathrm{Kg}$ leia-se

Zonas de inibição $(\mathrm{mm})$ produzidas por bactérias laticas isoladas sobre G. diazotrophicus nos meios MRS, D-MRS e $\mathrm{H}$, para as amostras coletadas no município de Itapetinga-B A

$10^{5} \mathrm{UFC} / \mathrm{g}$ ou $\left.\mathrm{ml}\right)$, quando ...

... (in the order of $10^{5} \mathrm{UFC} / \mathrm{g}$ or $\mathrm{mL}$ ), when ...

$\operatorname{kg}(25 \%$ da produção mundial), gerando uma produção de $14,8 \mathrm{x}$ $10^{9} \mathrm{~kg}$ de açúcar e $15,3 \times 10^{6} \mathrm{~m}^{3}$ de etanol.

reservas de nitrogênio do solo não é normalmente observado, mesmo após décadas, ou mesmo séculos de cultivo do solo com cana-de-açúcar (Reis Júnior, 2000).

Boddey et al. (1995) ao estudarem 10 variedades de cana-deaçúcar, ao longo de três anos, em um solo com baixo teor de nitrogênio $(0,108 \% \mathrm{~N})$, adubado com fósforo, potássio e micronutrientes e irrigado ...

incubação e padronização descritas no item 3.4.1. O processo de ...

NOVAES, F.V.

Nas "REFERÊNCIAS BIBLIOGRÁFICAS" verificou-se ausência da página 62, sendo esta adicionada após a página 67 . 
Dados Internacionais de Catalogação na Publicação (CIP) DIVISĀO DE BIBLIOTECA E DOCUMENTAÇĀO - Campus "Luiz de Queiroz"/USP

Maciel, Janeeyre Ferreira

Antagonismo de culturas láticas associadas com cana-de-açúcar sobre

G/uconacetobacter diazotrophicus / Janeeyre Ferreira Maciel. - - Piracicaba, 2001.

67 p. : il.

Tese (doutorado) - Escola Superior de Agricultura Luiz de Queiroz, 2001.

Bibliografia.

1. Bactéria fixadora de nitrogênio 2. Bactéria lática 3. Cana-de-açúcar 4. Lactobacilo 5. Microbiologia I. Título

$\operatorname{CDD} 589.95$

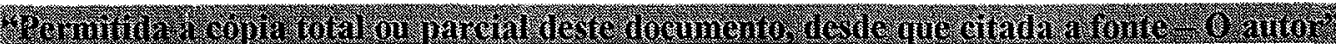


Dedico à minha mãe e a minha tia Maria 


\section{AGRADECIMENTOS}

\section{A DEUS}

A Universidade de São Paulo, pela oportunidade de realização desse Curso.

Ao professor Jorge Horii, pela orientação, pelo apoio e pela amizade

À Verônica Massena Reis, pela colaboração na execução desse trabalho

A todos que, direta ou indiretamente, contribuíram para a realização desse trabalho. 


\section{SUMÁRIO}

Página

LISTA DE FIGURAS.............................................................. vii

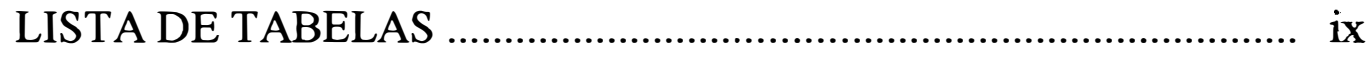

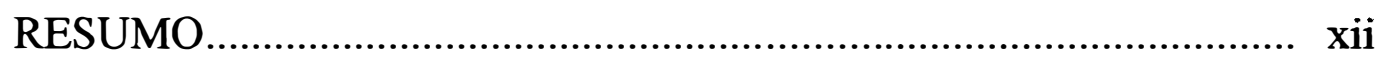

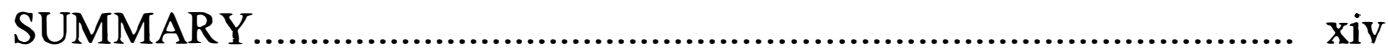

1 INTRODUÇÃO..................................................................... 1

2 REVISÃO DE LITERATURA..................................................... 3

2.1 Bactérias láticas associadas com cana-de-açúcar............................ 3

2.2 Características das bactérias láticas................................................ 6

2.3 Isolamento de bactérias láticas........................................................ 9

2.4 Antagonismo das bactérias láticas............................................. 10

2.5 Gluconacetobacter diazotrophicus e a fixação biológica de nitrogênio em cana-de-açúcar................................................... 14

2.6 Características de Gluconacetobacter diazotrophicus.................... 18

3 MATERIAL E MÉTODOS.......................................................... 21

3.1 Coleta e preparo das amostras...................................................... 21

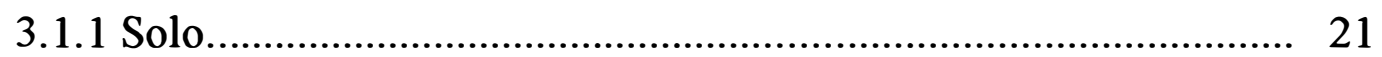

3.1.1.1 Determinação de pH do solo..................................................... 22

3.1.2 Água da bainha das folhas................................................... 22

3.1.3 Superficie dos colmos......................................................... 22 
3.2 Isolamento das bactérias láticas ............................................... 23

3.2.1 Caracterização dos isolados....................................................... 24

3.2.1.1 Método de Gram................................................................. 25

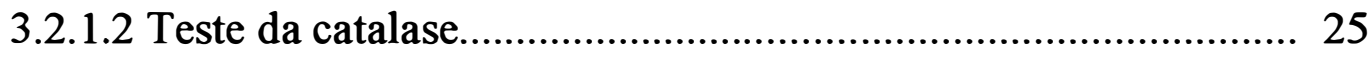

3.2.1.3 Teste da produção de gás a partir de glicose ............................. 25

3.3 Comparação de médias entre contagens: bactérias totais e bactérias láticas, na água da bainha das folhas............................. 26

3.3.1 Coleta e preparo das amostras.................................................... 26

3.3.2 Contagem de bactérias totais.................................................... 26

3.3.3 Contagem de bactérias láticas................................................. 27

3.4 Antagonismo das bactérias láticas sobre G. diazotrophicus............ 27

3.4.1 Método deferido................................................................... 27

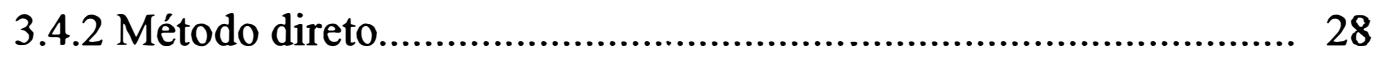

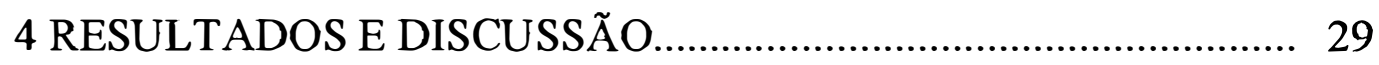

4.1 Contagem de bactérias láticas.................................................... 29

4.2. Isolamento de bactérias láticas.................................................... 34

4.3 Caracterização dos isolados....................................................... 36

4.3.1 Método de Gram..................................................................... 36

4.3.2 Teste da catalase e da produção de gás a partir de glicose............ 36

4.4 Comparação de médias entre contagens: bactérias totais e bactérias láticas na água da bainha das folhas de cana-de-açúcar... 37 
4.5 Antagonismo das bactérias láticas sobre G. diazotrophicus 38

5 CONCLUSÕES.......................................................................... 49

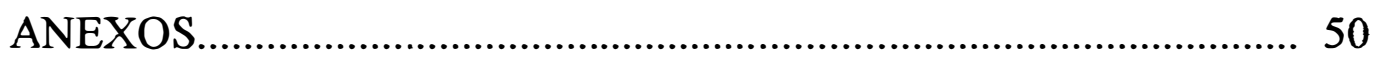

REFERÊNCIAS BIBLIOGRÁFICAS............................................ 56 


\section{LISTA DE FIGURAS}

Página

1 Zonas de inibição $(\mathrm{mm})$ produzidas por bactérias láticas isoladas sobre G. diazotrophicus no meio MRS, para a amostra de água da bainha coletada na cidade de Ivaí-PR

2 Zonas de inibição $(\mathrm{mm})$ produzidas por bactérias láticas isoladas sobre G. diazotrophicus no meio MRS, para a amostra da superfície dos colmos coletada na cidade de Ivaí-PR

3 Distribuição das zonas de inibição $(\mathrm{mm})$ observadas pelo método direto, para os isolados obtidos a partir das amostras coletadas em Ivaí-PR

4 Distribuição das zonas de inibição $(\mathrm{mm})$ observadas pelo método deferido, para os isolados obtidos a partir das amostras coletadas em Ivaí-PR

5 Distribuição das zonas de inibição $(\mathrm{mm})$ observadas pelo método deferido, para os isolados obtidos a partir das amostras coletadas em Piracicaba-SP. 
Página

6 Distribuição das zonas de inibição $(\mathrm{mm})$ observadas pelo método deferido, para os isolados obtidos a partir das amostras coletadas

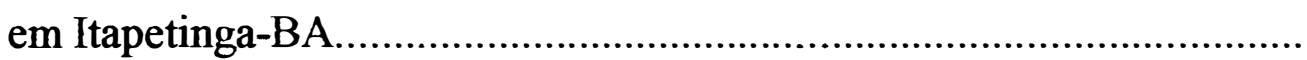




\section{LISTA DE TABELAS}

\section{Página}

1 Número de bactérias láticas (UFC/g) nas amostras de solo em profundidade de 0 a $20 \mathrm{~cm}\left(\mathrm{solo}_{\mathrm{s}}\right)$, coletadas nas cidades de Ivaí-PR, Piracicaba-SP e Itapetinga-BA.............................................. 30

2 Valores de $\mathrm{pH}$ para as amostras de solo $_{\mathrm{s}}$ e solo s $_{\mathrm{p}}$ coletadas nas cidades de Ivaí-PR, Piracicaba-SP e Itapetinga-BA.................................. 31

3 Número de bactérias láticas (UFC/g) nas amostras de solo em profundidade de 20 a $40 \mathrm{~cm}$ ( $\left(\right.$ solo $_{\mathrm{p}}$ ), coletadas nas cidades de Ivaí-PR, Piracicaba-SP e Itapetinga-BA....................................................

4 Número de bactérias láticas ( $\mathrm{UFC} / \mathrm{ml})$ nas amostras de água da bainha das folhas de cana-de-açúcar, coletadas nas cidades de Ivaí-PR, Piracicaba-SP e Itapetinga-BA

5 Número de bactérias láticas (UFC/ml) nas amostras de superfície dos colmos de cana-de-açúcar, coletadas nas cidades

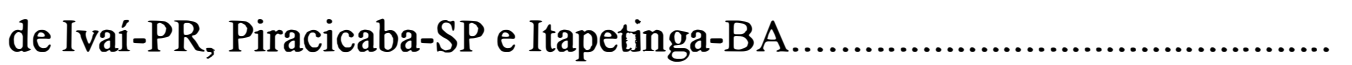


6 Número de bactérias láticas $\left(\mathrm{UFC} / \mathrm{cm}^{2}\right)$ nas amostras de superfície dos colmos de cana-de-açúcar, coletadas nas cidades de Ivaí-PR, Piracicaba-SP e Itapetinga-BA.

7 Número de isolados nos diferentes meios de cultura, para as amostras coletadas na cidade de Ivaí-PR

8 Número de isolados nos diferentes meios de cultura, para as amostras coletadas na cidade de Piracicaba-SP

9 Número de isolados nos diferentes meios de cultura, para as amostras coletadas na cidade de Itapetinga-BA

10 Zonas de inibição $(\mathrm{mm})$ produzidas por bactérias láticas isoladas sobre $G$. diazotrophicus nos meio MRS, D-MRS e H, para as amostras coletadas na cidade de Ivaí-PR

11 Zonas de inibição $(\mathrm{mm})$ produzidas por bactérias láticas isoladas sobre $G$. diazotrophicus nos meios MRS, D-MRS e H, para as amostras coletadas na cidade de Piracicaba-SP

12 Zonas de inibição $(\mathrm{mm})$ produzidas por bactérias láticas isoladas sobre G. diazotrophicus nos meios MRS, D-MRS e H, para as amostras coletadas na cidade de Itapetinga-BA. 
Página

13 Resultados estatísticos das contagens total de bactérias e de bactérias láticas (UFC/ml) nas amostras de água da bainha das folhas de cana-de-açúcar, coletadas na cidade de Itapetinga-BA............ 42 


\section{ANTAGONISMO DE CULTURAS LÁTICAS ASSOCIADAS COM CANA- DE-AÇÚCAR SOBRE}

Gluconacetobacter diazotrophicus

Autora: JANEEYRE FERREIRA MACIEL

Orientador: Prof. Dr. JORGE HORII

\section{RESUMO}

Bactérias láticas foram isoladas a partir das amostras de solo (nas profundidades de 0 a $20 \mathrm{~cm}$ e de 20 a $40 \mathrm{~cm}$ ), de água da bainha das folhas e da superficie dos colmos de cana-de-açúcar, coletadas nos municípios de Ivaí-PR, Piracicaba-SP e Itapetinga-BA. Para o isolamento das bactérias láticas, três diferentes meios de cultura foram utilizados: MRS, D-MRS e $\mathrm{H}$, adicionados de púrpura de bromocresol e carbonato de cálcio. Foram isoladas colônias representativas, circundadas por halo amarelo, em número igual à raiz quadrada do total de colônias na placa. Um total de 156 bactérias láticas foi isolado. O número de bactérias láticas foi maior nas amostras de solo e de água da bainha (na ordem de $10^{5} \mathrm{UFC} / \mathrm{g}$ ), quando comparado com amostras da superficie dos colmos de canade-açúcar (na ordem de $10^{3} \mathrm{UFC} / \mathrm{ml}$ ). Nas amostras de água da bainha das folhas de cana-de-açúcar, coletadas no município de Itapetinga-BA, em fevereiro de 2001, o número de bactérias láticas encontradas representa, aproximadamente, $10 \%$ da população total de bactérias. Dos 156 isolados, 74 foram avaliados 
quanto a atividade antagônica sobre G. diazotrophicus. Dos 74 isolados testados, 58 apresentaram zonas de inibição, sendo 11 observadas pelos dois métodos usados e 47 por apenas um método (10 pelo método direto e 37 pelo método deferido), com zonas de inibição variando de 3 a $10 \mathrm{~mm}$. Zonas de inibição maiores foram apresentadas pelo método deferido. Os isolados obtidos a partir das amostras coletadas em Piracicaba e Itapetinga só apresentaram zonas de inibição pelo método deferido, enquanto em Ivaí 11 isolados apresentaram zonas de inibição pelos dois métodos e 10 pelo método direto. Diferenças de até $3 \mathrm{~mm}$ nas zonas de inibição foram observadas entre os dois métodos. Para as amostras coletadas em Ivaí, 36,4\% dos isolados apresentaram zonas de inibição de até 5 $\mathrm{mm}$, pelo método deferido, enquanto $57,2 \%$ apresentaram zonas de inibição de $5 \mathrm{~mm}$, pelo método direto. Para as amostras coletadas em Piracicaba, zonas de inibição de até $5 \mathrm{~mm}$ foram produzidas por $75 \%$ dos isolados. Entretanto, todos os isolados obtidos a partir das amostras coletadas em Itapetinga apresentaram zonas de inibição $>5 \mathrm{~mm}$. 


\title{
ANTAGONISM OF LACTIC ACID BACTERIA ASSOCIATED WITH SUGAR CANE ON
}

Gluconacetobacter diazotrophicus

\author{
Author: JANEEYRE FERREIRA MACIEL \\ Adviser: Prof. Dr. JORGE HORII
}

\section{SUMMARY}

Lactic acid bacteria were isolated from the soil (in depths from 0 to $20 \mathrm{~cm}$ and 20 to $40 \mathrm{~cm}$ ), leaf-sheath water and sugar cane stalks surface samples, collected in Ivaí-PR, Piracicaba-SP and Itapetinga-BA. Three media were used for the isolation of the bacteria: MRS, D-MRS e $\mathrm{H}$, all containing bromocresol purple and calcium carbonate. A number of typical acid forming colonies, equal to the square root of their total numbers, was isolated from each plate. 156 lactic acid bacteria were isolated. The number of lactic acid bacteria was larger in the soil and leaf-sheath water samples (in the order of $10^{5} \mathrm{UFC} / \mathrm{g}$ ), when compared with sugar cane stalks surface samples (in the order of $10^{3} \mathrm{UFC} / \mathrm{mL}$ ). In the leaf-sheath water samples, collected in the Municipal District of Itapetinga-BA, in February of 2001, the number of the lactic acid bacteria found represents, approximately, $10 \%$ of the total population of bacteria. Of the 156 isolated, 74 were appraised as the antagonistic activity on G. diazotrophicus. Of the 74 isolated tested, 58 presented inhibition zones, being 11 observed by the two used methods and 47 for 
only a method ( 10 for the direct method and 37 for the deferred method), with inhibition zones varying from 3 to $10 \mathrm{~mm}$. Larger inhibition zones were formed by the deferred method. The isolated obtained from the samples collected in Piracicaba and Itapetinga only formed inhibition zones by the deferred method, while the ones from Ivaí 11 isolated formed inhibition zones by the two methods and 10 by the direct method. Differences up to $3 \mathrm{~mm}$ in inhibition zones were observed between the two methods. For the samples collected in Ivaí, $36,4 \%$ of the isolated formed inhibition zones up to $5 \mathrm{~mm}$ by the deferred method, while $57,2 \%$ formed inhibition zones up to $5 \mathrm{~mm}$, by the the direct method. In isolated from Piracicaba, inhibition zones up to $5 \mathrm{~mm}$ were formed for $75 \%$ of the isolated. However, all the isolated obtained from the samples collected in Itapetinga formed inhibition zones larger than $5 \mathrm{~mm}$. 


\section{INTRODUÇÃO}

Na fabricação de aguardente de cana, a fermentação alcoólica é a fase de mais dificil controle e onde ocorrem as maiores perdas operacionais. Essas são devidas principalmente às contaminações bacterianas, que podem afetar a viabilidade da levedura, levando a quedas na produtividade e rendimento fermentativo (Novaes, 1992).

Levantamentos sobre esses contaminantes demonstram a predominância de bactérias láticas, principalmente às do gênero Lactobacillus, sendo a espécie $L$. fermentum a de maior ocorrência (Gallo, 1991).

A contaminação por bactérias láticas inicia-se no campo, com a matériaprima e vai até a fábrica, durante as diferentes etapas do processo. Esses microrganismos encontram no caldo de cana um ótimo substrato para o seu crescimento e são bem adaptados às dornas de fermentação (Tilbury, 1975).

Os efeitos prejudiciais das bactérias láticas sobre a cana-de-açúcar após a colheita são bem conhecidos (Tilbury, 1975), entretanto, a importância da ocorrência e ação desses microrganismos sobre a planta em desenvolvimento tem sido pouco estudada (Hammes et al., 1992).

As interações de bactérias láticas com outras bactérias têm sido amplamente pesquisadas em produtos alimentícios e, especialmente, em alimentos fermentados (Adams, 1986). Em cana-de-açúcar, nenhuma informação sobre essas interações tem sido notificada. 
Considerando a importância da fixação biológica de nitrogênio para a cultura da cana-de-açúcar, faz-se necessário conhecer os efeitos produzidos pelo crescimento de bactérias láticas na presença de bactérias fixadoras de nitrogênio.

Gluconacetobacter diazotrophicus é uma bactéria de interesse especial em cana-de-açúcar porque, além de fixar nitrogênio na presença de nitratos e em valores baixos de $\mathrm{pH}(3,0)$, pode excretar quase a metade do nitrogênio fixado em uma forma potencialmente disponível para a planta (Cojho et al., 1993; Stephan et al., 1991).

Este trabalho teve como objetivos isolar bactérias láticas associadas com cana-de-açúcar e verificar "in vitro" o antagonismo dos isolados sobre Gluconacetobacter diazotrophicus. 


\section{REVISÃO DE LITERATURA}

\subsection{Bactérias láticas associadas à cana-de-açúcar}

A produção de álcool a partir de cana-de-açúcar enfrenta sérios problemas em relação a contaminantes, pois a matéria-prima leva consigo para dentro da indústria uma grande quantidade de microrganismos que tanto podem fazer parte da sua microbiota (Duncan \& Colmer, 1964) como estar na terra aderida aos colmos, raízes e folhas (Tilbury, 1975).

Estudos sobre a biodeterioração da cana colhida demonstram o aumento das populações de bactérias láticas no caldo obtido a partir de colmos inteiros estocados após a colheita. O número de bactérias láticas presentes nas amostras obtidas a partir de colmos recém-colhidos variou de $5 \times 10^{4} \mathrm{UFC} / \mathrm{mL}$ a $5 \times 10^{5}$ $\mathrm{UFC} / \mathrm{mL}$, atingindo valores máximos, na ordem de $10^{8} \mathrm{UFC} / \mathrm{mL}$, após 3-4 dias de estocagem. $\mathrm{O}$ número de leveduras inicialmente presentes nessas amostras variou de $10^{3}$ a $10^{4} \mathrm{UFC} / \mathrm{mL}$, atingindo valores máximos, na ordem de $10^{6} \mathrm{UFC} / \mathrm{mL}$, após 10 dias de estocagem. Exames morfológicos das bactérias isoladas nos primeiros 5 dias de estocagem indicam a ocorrência de cocos, cujas colônias apresentam aspecto mucóide, sendo esses microrganismos, provavelmente, pertencentes ao gênero Leuconostoc. Em estocagem prolongada, predominam colônias pequenas e opacas, com características típicas de bactérias do gênero Lactobacillus. Considerando a queda de $\mathrm{pH}$ do caldo de cana de 5,1 para 4,3, durante o período de estocagem, essa sucessão microbiana observada pode ser 
explicada pela maior sensibilidade à acidez de bactérias do gênero Leuconostoc, quando comparadas com as do gênero Lactobacillus. Dos 154 isolados identificados, ao nível de gênero, 87 pertenciam ao gênero Leuconostoc e 67 ao gênero Lactobacillus (Tilbury, 1975).

A biodeterioração da cana colhida por bactérias láticas causa importantes efeitos econômicos, dentre eles, a perda diária de sacarose que pode alcançar até $4,75 \%$ no período entre corte e moagem. Esse grupo de bactérias, formado por cocos e bacilos gram-positivos, produz ácido lático a partir de carboidratos fermentáveis da cana (Tilbury, 1975).

O alto teor de açúcares ( $15 \%$, em média) e o pH inicial de 5 a 5,5 tornam o caldo de cana um substrato ótimo para o crescimento de bactérias láticas. A temperatura e umidade elevadas, também, são fatores que favorecem a contaminação lática. Em climas quentes e úmidos, o crescimento de Leuconostoc mesenteroides subsp. mesenteroides em cana colhida pode resultar em perdas de 1 a $5 \%$ do açúcar total a cada dia entre colheita e processamento (Tilbury, 1975).

Durante a colheita, a cana está contaminada com L. mesenteroides subsp. mesenteroides, que é capaz de crescer no interior dos colmos cortados e causar acidifícação do caldo de cana (Egan, 1965; Stupiello \& Fernandes, 1984).

A queima da cana pode provocar rachaduras nos colmos e exsudação de um xarope, cuja perda de açúcares pode chegar a 14,5\%, oferecendo condições ao aumento de microrganismos, em relação à cana crua. A destruição da cera que envolve os colmos e exerce uma ação bacteriostática, também, contribui para esse aumento (Stupiello, 1992). Na Jamaica, onde a cana é queimada antes da colheita, foram feitos "swabs" nos colmos da cana verde e após a queima. Aproximadamente, 1/3 de ambas as amostras apresentaram L. mesenteroides (Tilbury, 1975). Portanto, a queima não constitui um problema para o crescimento de algumas bactérias, como o L. mesenteroides, que pode resistir a 
temperaturas de até $55^{\circ} \mathrm{C}$, temperatura atingida pelos colmos a cerca de $60-80 \mathrm{~cm}$ do nível do solo (Stupiello, 1992).

Bevan \& Bond (1971) isolaram cocos, pertencentes, principalmente, ao gênero Leuconostoc, a partir das rachaduras provocadas pelo crescimento dos colmos. Esses microrganismos mostraram-se muito ativos, evidenciando que essas fendas se constituem em excelentes sítios para o desenvolvimento microbiano.

A presença de bactérias láticas no solo depende do conteúdo de substratos fermentáveis. Por isso, são mais frequentes em solos cultivados e constituem uma parte da microbiota na rizosfera da planta, ou são lavadas da pilosfera (Hammes et al., 1992). Aproximadamente, 50\% de 19 amostras de solo, coletadas em diferentes áreas de plantio de cana, apresentaram Leuconostoc, em números que variavam de $10^{1}$ a $5 \times 10^{3} \mathrm{UFC} / \mathrm{g}$ de solo. A utilização da torta, obtida na filtração do caldo, como fertilizante nessas áreas, estava aumentando a contaminação com esse microrganismo. Possivelmente, as cápsulas de polissacarídeos formadas por Leuconostoc ajudaram este a sobreviver no solo (Tilbury, 1975). Mayeux, citado por Day (1992) observou uma maior incidência desse microrganismo no solo, em torno da planta de cana, ao nível de $45 \mathrm{~cm}$ de profundidade, sendo poucas vezes isolado na superfície.

As bactérias láticas mais comumente encontradas na rizosfera de plantas são Lactobacillus plantarum, Lactobacillus brevis e Lactobacillus fermentum (Kvasnikov et al., 1983).

Entre as bactérias láticas encontradas em plantas, Leuconostoc parece ser predominante, e L. mesenteroides subsp. mesenteroides é a espécie mais frequente (Holzapfel \& Schillinger, 1992). Os números de lactobacilos são bem mais baixos e na maioria das amostras menos que 10 lactobacilos/grama são detectados. A distribuição ampla de lactobacilos em plantas, apesar de em baixos 
números, sustentam a hipótese de que as plantas são um habitat primário para algumas espécies de Lactobacillus (Hammes et al., 1992).

\subsection{Características das bactérias láticas}

O grupo de bactérias láticas é formado por cocos e bacilos grampositivos, que apresentam muitas propriedades em comum, sendo a produção de ácido a partir de carboidratos fermentáveis a principal característica do grupo. Neste grupo estão incluídas espécies bacterianas dos gêneros Lactococcus, Leuconostoc, Pediococcus, Carnobacterium e Lactobacillus (Borch \& Molin, 1988; Hammes et al., 1992; Herrero et al., 1996).

As bactérias láticas mais comumente envolvidas com a biodeterioração da cana colhida pertencem aos gêneros Leuconostoc e Lactobacillus (Tilbury, 1975).

As bactérias do gênero Leuconostoc têm uma fisiologia similar à do gênero Lactobacillus. Filogeneticamente, esses dois gêneros são considerados inter-relacionados. Apesar de morfologicamente similares aos lactococos e outros estreptococos, Leuconostoc tem mais características em comum com os lactobacilos heterofermentativos do que com qualquer outro grupo de bactérias láticas (Holzapfel \& Schillinger, 1992).

O gênero Leuconostoc compreende 11 espécies, sendo que as associadas com a biodeterioração da cana colhida são $L$. mesenteroides subsp. mesenteroides e L. mesenteroides subsp. dextranicum (Tilbury, 1975; Holzapfel \& Schillinger, 1992). L. mesenteroides subsp. mesenteroides é aparentemente melhor adaptado a materiais de plantas, iniciando o crescimento mais rapidamente que outras bactérias láticas (Holzapfel \& Schillinger, 1992). As bactérias desse gênero têm seu crescimento favorecido a temperaturas de 20 a $30^{\circ} \mathrm{C}$, enquanto a maioria das 
bactérias láticas cresce mais rapidamente a $30-35^{\circ} \mathrm{C}$ (Nout, 1992). Esses microrganismos preferem meios relativamente ácidos a neutros e, com exceção de L. oenos, são menos acidúricos que lactobacilos. As condições de crescimento podem afetar a morfologia das células. Quando estas são cultivadas em leite, formam cocos; em outros meios líquidos, podem parecer bacilos; e em ágar, frequentemente apresentam-se na forma lenticular (Holzapfel \& Schillinger, 1992). McDonalds et al. (1990) observaram a tolerância a ácidos de Leuconostoc mesenteroides e de Lactobacillus plantarum. O crescimento de L. mesenteroides cessou quando seu $\mathrm{pH}$ interno atingiu 5,4-5,7 e o crescimento de $L$. plantarum, quando o pH interno foi de 4,6-4,8. A maioria das espécies de Leuconostoc é relativamente insensível ao oxigênio, apesar de melhor crescimento ser observado em condições de atmosfera reduzida (Holzapfel \& Schillinger, 1992).

A formação de gás, a partir de glicose, é uma característica que permite diferenciar as bactérias do gênero Leuconostoc das bactérias láticas homofermentativas. A maioria dos lactobacilos heterofermentativos formadores de gás, por hidrolisarem arginina e formarem DL- lactato, pode ser diferenciada das espécies de Leuconostoc, que não hidrolisam arginina e formam D-lactato. Entretanto, alguns lactobacilos heterofermentativos apresentam similaridades fenotípicas que tornam difícil esta separação (Holzapfel \& Schillinger, 1992).

L. mesenteroides subsp. mesenteroides pode produzir altas quantidades de dextrana, a partir de sacarose. Esse polissacarídeo causa uma série de complicações indesejáveis nos processos de produção de álcool e açúcar, tais como entupimento nas tubulações, centrífugas, peneiras e trocadores de calor (Gallo, 1991; Holzapfel \& Schillinger, 1992).

O gênero Lactobacillus compreende mais de 50 espécies reconhecidas. Lactobacillus plantarum, L. brevis e L. fermentum são as espécies mais comumente isoladas de plantas (Stirling \& Whittenbury, 1963; Hammes et al., 1992). 
As espécies do gênero Lactobacillus podem ser classificadas em três grupos: homofermentativos obrigatórios, heterofermentativos facultativos e heterofermentativos obrigatórios. $\mathrm{Na}$ fermentação homolática mais de $\mathbf{8 5 \%}$ do produto final é ácido lático e na fermentação heterolática, quantidades equimolares de ácido lático, dióxido de carbono $\left(\mathrm{CO}_{2}\right)$, etanol e/ou ácido acético são produzidas. Os lactobacilos heterofermentativos facultativos só efetuam a fermentação heterolática em limitação de glicose. A produção de gás a partir de glicose é uma característica de grande importância taxonômica na diferenciação entre espécies de lactobacilos homofermentativos e heterofermentativos (Hammes et al., 1992).

Lactobacilos são microrganismos fastidiosos, assim como as demais bactérias láticas. Requerem carboidratos, nucleotídeos, aminoácidos e vitaminas para o crescimento. Essas exigências normalmente são satisfeitas quando os meios contêm carboidratos fermentáveis, peptona, extrato de carne e de levedura. Suplementações com suco de tomate, manganês, acetato e ésteres de ácido oléico, especialmente "tween" 80, são estimulatórios, ou mesmo essenciais, para a maioria das espécies. Preferem meios relativamente ácidos com um $\mathrm{pH}$ de 6,4 a 4,5. A formação de ácido lático a partir de carboidratos fermentáveis reduz o pH do meio a valores abaixo de 4,0. Essa redução de $\mathrm{pH}$ previne o crescimento de outros microrganismos competidores (Kandler \& Weiss, 1986); o crescimento em superfícies de meios sólidos é aumentado por anaerobiose ou pressão de oxigênio reduzida com 5 a $10 \%$ de $\mathrm{CO}_{2}$; alguns são anaeróbios no isolamento. $\mathrm{O}$ comprimento dos bacilos e o grau de curvatura dependem da idade da cultura, da composição do meio e da tensão de oxigênio. Cocobacilos podem tornar-se tão curtos que podem ser confundidos com Leuconostoc e Streptococcus. Algumas espécies de Lactobacillus produtores de gás exibem sempre uma mistura de bacilos longos e curtos (ex: L. fermentum e L. brevis) (Hammes et al., 1992). 
Algumas espécies de Lactobacillus adquirem atividade de catalase quando crescem na presença de uma fonte de heme. Outro mecanismo importante na eliminação de metabólitos tóxicos de oxigênio é o acúmulo intracelular de manganês (Hammes et al., 1992; Stanier et al., 1986).

\subsection{Isolamento de bactérias láticas}

Os procedimentos utilizados em isolamento de bactérias láticas são bastante similares. A amostra, após o preparo, é diluída, semeada em meios próprios e incubada em condições favoráveis ao grupo de microrganismos de interesse. Após o crescimento, as colônias típicas são subcultivadas em meios apropriados até a obtenção da cultura pura. Quando as características observadas no meio são as esperadas, bem como quando a coloração de Gram e a morfologia das colônias e das células forem típicas das bactérias de interesse, essas são submetidas a outros testes, para fins de identificação (Chaves, 1991; Morishita \& Shiromizu, 1986).

Vários meios de cultura têm sido recomendados para a contagem de bactérias láticas. Entretanto, não se dispõe de um único meio seletivo satisfatório para recuperar e enumerar todos os membros desse grupo (Geraldini et al., 1979; Hammes et al., 1992).

Meios para o isolamento de Lactobacillus devem considerar sua natureza acidofilica ou acidúrica e seus requerimentos nutricionais complexos. Um baixo $\mathrm{pH}$, variando de 4,5 a 6,2 favorece o crescimento. Quando a população predominante é de lactobacilos o ágar MRS pode ser usado no isolamento (Hammes et al., 1992). O uso de uma camada de cobertura e a incorporação de cisteína-HCl $0,1 \%$ ao meio MRS permite a substituição da incubação anaeróbica, comumente recomendada para bactérias láticas, por incubação aeróbica (Holly et 
al., 1991). O meio MRS com $\mathrm{pH}$ ajustado para 5,7 permite o isolamento de muitas espécies de Lactobacillus, Leuconostoc e Pediococcus (Garvie, 1986; Holzapfel \& Schillinger, 1992).

$\mathrm{O}$ crescimento de lactobacilos especialmente fastidiosos, principalmente, espécies heterofermentativas obrigatórias, tem sido favorecido no meio Homohiochii modificado, com $\mathrm{pH}$ ajustado para 5,4 e adicionado de $40 \mathrm{~mL}$ de etanol/L (Hammes et al., 1992). A substituição parcial ou total da glicose por outros carboidratos tais como maltose, frutose, sacarose ou arabinose é recomendada em alguns casos, especialmente quando lactobacilos heterofermentadores exibem um importante papel (Kandler e Weiss, 1986).

As bactérias do gênero Leuconostoc são tipicamente associadas com populações mistas de bactérias láticas em alimentos e plantas. Com exceção da natureza acidúrica, apresentam exigências nutricionais semelhantes às dos Lactobacillus. O meio MRS, também, pode ser usado no seu isolamento, entretanto, não é possível a diferenciação direta entre Lactobacillus e Leuconostoc nesse meio (Holzapfel \& Schillinger, 1992). Quando o $\mathrm{pH}$ do meio MRS é ajustado para 8-9, ocorre a inibição de Lactobacillus que são frequentemente encontrados em associação com Leuconostoc. Essa elevação de $\mathrm{pH}$ requer substituição de glicose por sacarose a fim de reduzir reações de "Maillard" durante o tratamento em autoclave. Essas modificações, juntamente com a exclusão do acetato, conferem ao ágar MRS a denominação de ágar DMRS (Hammes et al., 1992).

\subsection{Antagonismo das bactérias láticas}

Em uma variedade de alimentos fermentados, as bactérias láticas atuam como agentes de preservação. A ação antibacteriana desses microrganismos tem 
sido atribuída à produção de certos metabólitos tais como ácidos orgânicos, dióxido de carbono $\left(\mathrm{CO}_{2}\right)$, peróxido de hidrogênio $\left(\mathrm{H}_{2} \mathrm{O}_{2}\right)$, diacetil e bacteriocinas, entre outras (Eamshaw, 1992).

Recentemente, alguns pesquisadores têm se interessado pelo uso de bactérias láticas no controle biológico de doenças bacterianas em plantas. Pesquisas utilizando bactérias láticas isoladas de plantas demonstram o antagonismo desses microrganismos sobre bactérias fitopatogênicas tais como Xanthomonas campestris, Erwinia carotovora e Pseudomonas syringae (Visser et al., 1986; Visser \& Holzapfel, 1992).

As bactérias láticas produzem ácidos orgânicos, os quais são capazes de inibir o crescimento de diversos microrganismos. $\mathrm{O}$ efeito antimicrobiano desses ácidos é devido à redução no $\mathrm{pH}$ e à forma não dissociada, que por ser mais solúvel na membrana celular, interfere com sua permeabilidade e impede a fosforilação oxidativa a partir do sistema de transporte de elétrons. Também, promove acidificação do conteúdo da célula, causando sua morte (Cliver \& Marth, 1990). Além do ácido lático, o ácido acético e o ácido propiônico são produzidos em quantidades traço por uma grande variedade de bactérias láticas. Esses têm maior valor de $\mathrm{pK}_{\mathrm{a}}$ do que ácido lático e, portanto, têm uma maior taxa de ácido não dissociado em um dado $\mathrm{pH}$. Essa diferença pode ser uma razão para a maior eficácia antimicrobiana desses ácidos quando comparada ao ácido lático (Earnshaw, 1992). A capacidade permeabilizante do ácido lático sobre a membrana externa de bactérias gram-negativas potencializa a ação antimicrobiana de diversos metabólitos tais como reuterina e bacteriocinas, entre outros (Alakomi et al., 2000). Um aumento gradual da acidez pode tornar o microrganismo tolerante ao ácido, permitindo sua sobrevivência quando submetido a exposições subsequentes, as quais seriam letais para células não tolerantes (Alakomi et al., 2000). 
Algumas bactérias láticas são capazes de produzir peróxido de hidrogênio $\left(\mathrm{H}_{2} \mathrm{O}_{2}\right)$. Esse metabólito é produzido por Lactobacillus acidophillus em concentrações suficientes para inibir grupos bem diversificados de microrganismos, incluindo patógenos intestinais como Salmonella, Shigella e outras bactérias relevantes em distúrbios gastrintestinais no homem. A concentração de $\mathrm{H}_{2} \mathrm{O}_{2}$ produzida está relacionada às condições de cultivo, observando-se que o crescimento em meio com baixa concentração de glicose altera a fisiologia do microrganismo, aumentando nitidamente a produção de peróxido (Ribeiro, 1995). $\mathrm{O} \mathrm{H}_{2} \mathrm{O}_{2}$ pode reagir com outras substâncias e formar compostos ainda mais inibidores. Ao reagir com tiocianatos, na presença da enzima lactoperoxidase, forma o radical tóxico hipotiocianato cuja ação antibacteriana deve-se, principalmente, a oxidação dos grupos sulfidrilos de enzimas e proteínas (Reiter \& Harnulv, 1984). Esse metabólito também pode reagir com superóxido e formar o radical hidroxil, que é muito mais reativo e poderoso oxidante de biomoléculas (Reiter \& Harnulv, 1984).

Outro importante metabólito sintetizado por algumas espécies de bactérias láticas é o diacetil, composto reconhecido pelo aroma característico que confere a certos alimentos e também pela sua ação antimicrobiana. É mais efetivo em temperaturas de 10 a $20^{\circ} \mathrm{C}$, na presença de glicose e em valores de $\mathrm{pH}$ mais baixos. Em concentração de $200 \mathrm{mg} / \mathrm{kg}$ exerce efeito inibitório sobre bactérias gram-negativas (Jay, 1982). A fermentação de citrato produz diacetil, uma propriedade comum entre algumas espécies de Lactococcus, Lactobacillus e Leuconostoc (Earnshaw, 1992).

$\mathrm{O}$ antagonismo em bactérias láticas também tem sido associado a substâncias protéicas com espectro de inibição mais restrito, as bacteriocinas, as quais apresentam natureza protéica e não são letais às estirpes produtoras. No gênero Lactobacillus várias espécies são citadas como produtoras de bacteriocinas: L. fermentum, L. helveticus, L. plantarum, L. sake, L. bavaricus, $L$. 
acidophilus e L. casei (Nettles \& Barefoot, 1993). Nisina é uma bacteriocina produzida por certas cepas de Lactococcus lactis, que atuam apenas sobre bactérias gram-positivas. Entretanto, bactérias gram-negativas com falhas em sua parede celular externa podem ser afetadas. A nisina, também, tem potencial para uso em indústrias de bebidas alcoólicas, onde poderá inibir bactérias grampositivas indesejáveis, as quais competem com as leveduras, reduzindo produtividade alcoólica e, em alguns casos, causando deterioração (Earnshaw, 1992).

Lactobacilos também têm sido citados como produtores de substâncias inibidoras não protéicas, com espectro de inibição mais amplo: acidolina foi referida por Hamdam \& Mikolajcik (1974) como um antibiótico. Produzida por L. acidophilus, mostrou-se efetiva na inibição de bactérias gram-positivas e gramnegativas como Staphylococcus aureus, Lactococcus sp., Lactobacillus sp., Bacillus cereus, Escherichia coli e Salmonella. Outro composto inibidor, a reuterina, é produzido por algumas cepas de L. reuteri. Pode ser obtida em maiores quantidades durante o crescimento desse microrganismo em anaerobiose, na presença de glicerol. A reuterina é ativa contra Staphylococcus sp., Candida sp., Clostridium sp., Salmonella sp. e Shigella sp. Seu espectro antimicrobiano inclui bactérias gram-positivas e gram-negativas, leveduras e o agente causal da doença de Chagas. Também, tem sido reportado que o contato célula-célula com microrganismos diferentes estimula a produção de reuterina (Axelsson et al, 1989). Algumas espécies de Lactobacillus e Lactococcus apresentam atividade lipolítica e, sob certas condições, são produzidas concentrações significativas de ácidos graxos, os quais apresentam atividade antimicrobiana (Eamshaw, 1992). 


\subsection{Gluconacetobacter diazotrophicus e a fixação biológica de nitrogênio em cana-de-açúcar}

No Brasil, a área cultivada com cana-de-açúcar é de aproximadamente 4,7 milhões de hectares, a qual, em 1997, representou uma produção de $3 \times 10^{11}$ $\mathrm{kg}$

( $25 \%$ da produção mundial), gerando uma produção de $14,8 \times 10^{9} \mathrm{~kg}$ de açúcar e $15,3 \times 10^{6} \mathrm{~m}^{3}$ de etanol. Essa cultura consome mais de $24 \times 10^{6} \mathrm{~kg}$ de nitrogênio/ano, o que representa custos de $\mathrm{R} \$ 150$ milhões, no Brasil (Reis Júnior et al., 2000).

A queima das folhas deixadas no solo dos canaviais deveria causar o esgotamento das reservas de nitrogênio, de modo que a produtividade eventualmente declinasse. Entretanto, tal declínio na produtividade ou nas reservas de nitrogênio do solo não é normalmente observado, mesmo após nitrogênio $(0.108 \% \mathrm{~N})$, adubado com fósforo, potássio e micronutrientes e irrigado durante o experimento verificou que a produtividade da cana foi alta durante o primeiro ano, variando de 175 a $230 \times 10^{3} \mathrm{~kg} / \mathrm{ha}$ e nas variedades CB45-3 e SP70-1143 essas taxas foram mantidas durante os dois anos subsequentes. Nessas mesmas variedades e na variedade Krakatau, da espécie Saccharum spontaneum, o acúmulo de nitrogênio, também, continuou alto e estável ao longo dos três anos. Entretanto, outras variedades (ex: CB47-89, NA56-79, SP71-799, Chunee) apresentaram um declínio no conteúdo de nitrogênio total após o primeiro ano, o que era esperado considerando a redução na disponibilidade de nitrogênio do solo. Em Pernambuco, Oliveira et al. (1994) ao investigar o efeito da queima pré-colheita sobre a produtividade da cana-deaçúcar e o acúmulo de nitrogênio da cultura, ao longo de 9 anos, , encontraram que o acúmulo de nitrogênio foi maior que o valor de nitrogênio inicial em até $620 \mathrm{~kg} / \mathrm{ha}$. Essa taxa de nitrogênio adicional foi atribuída a uma fixação biológica 
de nitrogênio anual média de 38 a $77 \mathrm{~kg} / \mathrm{ha}$, para essa cultura. Estudos efetuados no EMBRAPA-CNPAB indicam que em torno de 40 a $60 \%$ do nitrogênio da cana planta é derivado da fixação biológica de nitrogênio (FBN) e a extrapolação para as condições de campo sugere entrada de $150 \mathrm{~kg} \mathrm{~N} \cdot \mathrm{ha}^{-1}$.ano ${ }^{-1}$ (Lima et al., 1987). Certas variedades de cana-de-açúcar, ao receberem adubação com fosfato, aplicações de "sprays" com molibdênio ( $500 \mathrm{~g} / \mathrm{ha}$ ) e irrigação, podem superar esse valor (Reis Júnior et al., 2000).

Em cana-de-açúcar, observam-se variações entre os genótipos da planta em relação à taxa de FBN (Singh, 1994; Urquiaga et al., 1992). Uma possível explicação para tais variações seria o fato de que variedades diferentes apresentariam características distintas em relação à população de bactérias endofíticas. Entretanto, os resultados obtidos por Reis Júnior et al. (2000), demonstram não haver diferença significativa quanto ao número das bactérias endofiticas avaliadas (Herbaspirillum spp. e G. diazotrophicus) em 4 genótipos de cana-de-açúcar. Esses pesquisadores sugerem que, mesmo apresentando números similares de diazotróficos, é possível ocorrerem diferenças entre os genótipos nas interações planta $\mathrm{x}$ microrganismos. A diversidade genética de bactérias diazotróficas da mesma espécie relacionada com o genótipo da planta, também, deve ser considerada. Outra possibilidade que não pode ser descartada está relacionada com a presença de uma ou mais bactérias ainda não descritas.

Mais recentemente, uma nova espécie de bactéria fixadora de nitrogênio, Gluconacetobacter diazotrophicus, tem sido isolada a partir de diferentes variedades de cana-de-açúcar em diversas regiões do Brasil, bem como no México, Cuba e Austrália (Fuentes-Ramirez et al., 1993; Li \& MacRae, 1992), em números que variam de $10^{3}$ a $10^{7}$ células/g no interior das raízes, colmos basais e apicais, folhas e resíduos de folhas deixados no solo (Döbereiner et al., 1988). Esse microrganismo só tem sido isolado de plantas ricas em sacarose tais como cana-de-açúcar, batata doce e capim "cameroon", os quais são propagados 
vegetativamente (James et al., 1994). A capacidade de fixar nitrogênio, mesmo na presença de nitratos e a melhor adaptação ao ambiente da cana-de-açúcar (Cavalcante \& Döbereiner, 1988), conferem a G. diazotrophicus maior importância econômica quando comparado com outros diazotróficos associados com essa cultura (Fuentes-Ramirez et al., 1993). Sua eficiência em transferir o nitrogênio fixado foi observada pela primeira vez por Cojho et al. (1993). Esses pesquisadores demonstraram, em um sistema modelo para estudos "in vitro" de interações planta-bactéria, que $G$. diazotrophicus transfere em torno de $50 \%$ do nitrogênio fixado para uma levedura amilolítica, associada a esta em cultura mista.

A infecção e a colonização da cana-de-açúcar por $G$. diazotrophicus têm sido demonstradas por meio de microscopia eletrônica e óptica. Essa bactéria parece aderir às raízes via uma substância mucóide, que circunda a célula. Esse muco parece conter exopolissacarídeos, os quais têm se mostrado altamente imunogênicos em outras bactérias diazotróficas gram-negativas. Na superfície da raiz, a bactéria concentra-se nas regiões de junção de raízes laterais. Dentro da raiz, pode ser vista dentro das células da epiderme e nos espaços intercelulares do parênquima, bem como dentro de vasos do xilema, através dos quais a bactéria parece migrar para a parte aérea da cana. Esse microrganismo não sobrevive por muito tempo no solo sendo, provavelmente, transferido para uma nova planta através dos colmos usados como sementes (James et al., 1994). Sua natureza endofítica também foi confirmada por Reis et al. (1994) através de contagens realizadas a partir de amostras de raízes, colmos e partes aéreas da cana-deaçúcar, tanto nos estádios iniciais do crescimento como na maturação. Os números encontrados em todas as partes da planta analisadas variaram de $10^{3} \mathrm{a}$ $10^{6}$ células/grama. Esse microrganismo também foi isolado dos vasos do xilema (Reis, 1991). Algumas pesquisas sugerem que G. diazotrophicus localiza-se nos nós dos colmos (Reis, 1991), onde os tecidos densos do parênquima, 
armazenadores de sacarose, juntamente com pequenas quantidades de tecido vascular interconectados, possivelmente, proporcionem uma tensão de oxigênio reduzida e um suprimento satisfatório de fonte de energia para o microrganismo. Entretanto, a localização exata desse microrganismo nos nós dos colmos maduros ainda não foi determinada (James et al., 1994).

Fuentes-Ramirez et al. (1993), ao isolarem bactérias endofiticas, em diversas regiões do México, observaram a ocorrência de G. diazotrophicus, numa frequência de isolamento que variou de 1,1 a $67 \%$, em raízes e no interior dos colmos. As mais baixas frequências de isolamento (1,1 a 2,5\%) foram obtidas em locais onde a taxa de fertilização nitrogenada foi elevada $(275-300 \mathrm{~kg} / \mathrm{ha})$. Outro fator a ser considerado é que em algumas variedades de cana-de-açúcar (CP 29 203, MEX 68808 e MEX 76 646), localizadas nessa área, não foi possível isolar esse microrganismo. Contrariamente, maiores frequências (10 a 67\%) foram observadas em locais onde a taxa de fertilização nitrogenada foi de $120 \mathrm{~kg} / \mathrm{ha}$, sendo o microrganismo isolado de todos os cultivares presentes nessa área. Esses resultados sugerem que associações entre bactérias fixadoras de nitrogênio e plantas podem ser severamente limitadas quando fertilizantes nitrogenados são utilizados em quantidades excessivas no solo. Com relação as diferentes partes dos colmos, esses pesquisadores observaram uma maior frequência de isolamento de $G$. diazotrophicus na região apical, quando comparada com as regiões intermediária e basal. Provavelmente, essa distribuição preferencial deve ser regulada pela qualidade e quantidade dos açúcares solúveis que prevalecem em uma região particular da planta.

Em São Paulo, os colmos usados no plantio da cana são, normalmente, submetidos a um tratamento térmico $\left(52^{\circ} \mathrm{C}\right.$ por 30 minutos) a fim de eliminar o patógeno de planta Clavibacter xyli subsp. xili. A ocorrência de G. diazotrophicus em plantas de cana submetidas a tal tratamento foi comparada com sua ocorrência em plantas não tratadas. Não foram observadas diferenças 
significativas entre as duas amostras confirmando a tolerância desse diazotrófico à temperatura usada (Reis et al., 1994), como tem sido observado em condições de cultura pura (Reis, 1991).

Algumas cepas de G. diazotrophicus são capazes de produzir indol, em concentrações de 19 a $65 \mu \mathrm{g} / \mathrm{mL}$. O ácido indolacético produzido por esse microrganismo pode promover radificação e melhorar o crescimento da cana-deaçúcar por efeitos diretos sobre processos metabólicos (Fuentes-Ramirez et al., 1993).

\subsection{Características de Gluconacetobacter diazotrophicus}

Gluconacetobacter diazotrophicus é uma bactéria diazotrófica endofítica obrigatória, gram-negativa, em forma de bacilo curto, com diâmetro variando de 0,7 a $0,9 \mu \mathrm{m}$ (James et al., 1994), adaptada às condições de pressão osmótica e $\mathrm{pH}$, que prevalecem no interior da cana-de-açúcar (Cavalcante \& Döbereiner, 1988). Esse microrganismo, isolado pela primeira vez por Cavalcante \& Döbereiner (1988), foi, inicialmente, denominado como Acetobacter diazotrophicus (Gillis et al., 1989). Por possuir ubiquinona Q10, pertencia ao subgênero Gluconoacetobacter (Yamada \& Kondo, 1984). Recentemente, Yamada et al. (1997) propuseram a elevação desse subgênero ao nível de gênero, após analisarem as sequências de bases parciais do gene $\mathrm{RNA}_{\mathrm{r}} 16 \mathrm{~S}$ do microrganismo. O nome Gluconoacetobacter, por ser ortograficamente incorreto (Yamada et al., 1998), foi corrigido para Gluconacetobacter, sendo reconhecido e publicado no "International Journal of Systematic Bacteriology". Esse microrganismo utiliza o $\mathrm{N}_{2}$ como única fonte de nitrogênio quando cultivado em meio semi-sólido (condições microaeróbicas). Em meio líquido, requer a adição de uma fonte de nitrogênio. Seu metabolismo é respiratório e utiliza o oxigênio 
como aceptor final de elétrons. O ciclo do ácido tricarboxílico e a via da hexose monofosfato são as rotas metabólicas utilizada s (Cavalcante \& Döbereiner, 1988). Em meio LGI forma colônias pequenas $(<1 \mathrm{~mm})$ quando próximas às colônias de outras bactérias, ou maiores ( 2 a $3 \mathrm{~mm}$ ), quando em cultura pura ou quase pura. Nesse meio, o microrganismo inicia o crescimento, após 24-48 horas, com formação de película e produção de ácido. As colônias inicialmente pequenas, brancas, mucosas, lisas e irregulares, tomam-se grandes, amarelo-escuras, laranja e finalmente vermelho-escuras, pois assimilam o azul de bromotimol presente no meio de cultura. Em ágar batata adicionado de sacarose $10 \%$, colônias marromescuras são formadas após 10 dias de incubação (Cavalcante \& Döbereiner, 1988; Reis et al., 1994).

Dentre as propriedades fisiológicas características dessa espécie de bactéria destaca-se a tolerância à altas concentrações de açúcares e à acidez (Cavalcante \& Döbereiner, 1988). G. diazotrophicus apresenta crescimento ótimo em concentrações de $10 \%$ de glicose ou de $15 \%$ de sacarose, apesar de crescer em concentrações de até 30\% desses açúcares (Cavalcante \& Döbereiner, 1988; Franke et al.,1999). Seu pH ótimo de crescimento é 5,5, mas consegue crescer e fixar nitrogênio em pH 3,0 ou menos, por vários dias (Cavalcante \& Döbereiner, 1988; Stephan et al., 1991). Quando o ácido acético é usado para ajustar o pH do meio de cultura, maior tolerância e rapidez de crescimento são observadas, sendo o pH ótimo 3,9. A adição de extrato de levedura ao meio, também, melhora a tolerância do microrganismo à acidez (Cavalcante \& Döbereiner, 1988).

O meio LGI modificado, semi-sólido e livre de nitrogênio, mostrou ser o mais seletivo para a pesquisa de G. diazotrophicus. Das diferentes fontes de sacarose testadas como fontes de carbono nesse meio, o açúcar de cana cristalizado proporcionou o mais rápido crescimento de $G$. diazotrophicus. A adição de $5 \mathrm{~mL} / \mathrm{L}$ de caldo de cana também favoreceu o crescimento desse microrganismo, sugerindo que algumas impurezas não identificadas da cana-de- 
açúcar poderiam ser as responsáveis por esse efeito (Reis et al., 1994). Etanol, acetato e lactato também são usados como fontes de carbono por $G$. diazotrophicus, sendo oxidados até dióxido de carbono $\left(\mathrm{CO}_{2}\right)$ e água (Franke et al., 1999). Em meio com $10 \%$ de sacarose, observa-se uma concentração ótima de oxigênio dissolvido para a redução de acetileno $(0.2 \mathrm{kPa})$, apesar de continuar fixando nitrogênio em concentrações acima de $4.0 \mathrm{kPa}$, apresentando uma tolerância ao oxigênio bem maior que Azospirillum spp. (Reis et al., 1990). A acidificação desse meio por $G$. diazotrophicus foi estudada após a adição de $1 \%$ de um dos seguintes compostos: manitol, glicerol e etanol. Nenhuma produção de ácido ocorreu na presença de manitol, mas houve uma queda de $\mathrm{pH}$ de 5,5 para 4,7 , com glicerol. A produção de ácido a partir de etanol foi muito mais rápida $\mathrm{e}$ pronunciada e o $\mathrm{pH}$ caiu para 2,8, após 48 horas (Cavalcante \& Döbereiner, 1988).

Silva et al., citados por Reis Júnior et al. (2000) ao compararem as técnicas do número mais provável (NMP) e do ensaio imunossorbente ligado à enzima (ELISA) quanto aos valores obtidos para as populações de $G$. diazotrophicus no interior dos tecidos da cana-de-açúcar, observaram as maiores estimativas ( 2 a 140 vezes maior) quando a técnica ELISA foi usada. Em cortes de colmos usados como sementes e solos não rizosféricos, onde as populações desse microrganismo são muito pequenas, o método ELISA não conseguiu detectá-las, sendo necessário um enriquecimento da amostra em meio de sacarose semi-sólido descrito por Li \& MacRae (1991).

G. diazotrophicus pode infectar um fungo micorrízico vesiculoarbuscular (VAM) e permanecer viável mesmo após dois meses de estocagem dos esporos do fungo a $4^{\circ} \mathrm{C}$. Estudos indicam que o fungo VAM Glomus clarum aumenta a possibilidade de migração de $G$. diazotrophicus para a parte aérea da planta (Paula et al., 1991). 


\section{MATERIAL E MÉTODOS}

Para o isolamento das bactérias láticas foram coletadas amostras de solo, de água da bainha das folhas e da superfície dos colmos da cana-de-açúcar, em três diferentes áreas de plantio. Em cada área, uma única touceira em estádio inicial de desenvolvimento foi selecionada.

\subsection{Coleta e preparo das amostras}

A coleta das amostras foi realizada no ano 2000, durante o mês de fevereiro, nos municípios de Ivaí-PR e Piracicaba-SP e no mês de setembro, no município de Itapetinga-BA.

\subsubsection{Solo}

Amostras de solo constituídas por 15 sub-amostras foram coletadas, em ziguezague, ao redor de touceiras de cana com auxílio de trado, nas profundidades de 0 a $20 \mathrm{~cm}$ e de 20 a $40 \mathrm{~cm}$. Todas as sub-amostras foram 
homogeneizadas e peneiradas, retirando-se porções de $25 \mathrm{~g}$, que foram diluídas em $225 \mathrm{~mL}$ de água peptonada $0,1 \%$ (Raij, 1991).

\subsubsection{Determinação de pH do solo}

Amostras de $10 \mathrm{~cm}^{3}$ de terra foram homogeneizadas em $25 \mathrm{~cm}^{3}$ de solução de cloreto de cálcio $0,01 \mathrm{M}$, sendo mantidas em repouso por 30 minutos. Após esse tempo, foi feita a agitação lenta das amostras por 15 minutos. A leitura de $\mathrm{pH}$ foi efetuada 30 minutos após, em potenciômetro Quimis 400A (Tomé Júnior., 1997).

\subsection{2 Água da bainha das folhas}

Amostras de $1 \mathrm{~mL}$ de água da bainha das folhas foram coletadas em tubos de ensaio esterilizados, contendo $9 \mathrm{~mL}$ de água peptonada $0,1 \%$, por uso de seringas esterilizadas.

\subsubsection{Superfície dos colmos}

Com "swabs" esterilizados umidecidos em água peptonada $0,1 \%$, foram realizados movimentos sobre a superfície dos colmos, numa inclinação de $45^{\circ}$ iniciando-se da esquerda para a direita, no sentido de cima para baixo. Após a coleta, os "swabs" foram imersos em tubos de ensaio com $10 \mathrm{~mL}$ de água peptonada, tendo sido a parte manuseada da haste, quebrada na borda interna do tubo. Para o cálculo dos resultados, que foram expressos em UFC/mL ou $\mathrm{UFC} / \mathrm{cm}^{2}$ de amostra, foram feitas medições da área amostrada com uma fita 
métrica. Inicialmente, calculou-se o número de $\mathrm{UFC} / \mathrm{mL}$ de suspensão. Essa suspensão, foi considerada como se fosse uma amostra sem diluição $\left(10^{0}\right)$. Em seguida, converteu-se o valor de UFC/mL de suspensão em UFC/ $\mathrm{cm}^{2}$ de amostra (Silva et al., 1997).

A partir das suspensões obtidas nos itens 3.1.1, 3.1.2 e 3.1.3, foram feitas as diluições necessárias à obtenção de colônias isoladas em placas.

\subsection{Isolamento das bactérias láticas}

As amostras, devidamente diluídas em água peptonada $0,1 \%$, foram semeadas nos seguintes meios: MRS (para bactérias láticas acidófilas) com $\mathrm{pH}$ ajustado para 5,7; D-MRS (para bactérias láticas não acidófilas) com pH ajustado para 8,0; Homohiochii modificado $(\mathrm{H})$ (para bactérias láticas heterofermentativas obrigatórias) com $\mathrm{pH}$ ajustado para 5,4. Todos os meios receberam ágar 1,5\% (Hammes et al., 1992). O plaqueamento foi feito em duplicata e a técnica do "spread plate" foi empregada. A adição de cisteína-HCl $0,1 \%$ e de uma camada de cobertura (meio com ágar $0,75 \%$ ) aos meios de cultura permitiram a incubação das bactérias láticas em aerobiose (Holly et al., 1991). Todos os meios foram modificados pela adição de púrpura de bromocresol e de carbonato de cálcio nas proporções de $0,004 \mathrm{~g} / 100 \mathrm{~mL}$ e $0,5 \mathrm{~g} / 100 \mathrm{~mL}$, respectivamente. As bactérias láticas produzem o ácido lático a partir de carboidratos e, devido ao abaixamento do $\mathrm{pH}$, em corante púrpura de bromocresol, apresenta cor amarelo. A função do carbonato de cálcio é evitar a difusão do ácido produzido no meio, tornando evidente a presença de halos amarelos em torno das colônias. Após incubação a $35^{\circ} \mathrm{C} / 48 \mathrm{~h}$, foram contadas e isoladas as colônias circundadas por halo amarelo (Chaves, 1991). As placas com cerca de 25 a 250 colônias foram selecionadas e contadas, utilizando-se o contador de colônias Quebec. Dessas 
placas, foi isolado, aleatoriamente, um número de colônias igual ao da raiz quadrada da contagem total. Cada colônia foi transferida, com alça de platina, para um meio similar ao utilizado no isolamento, utilizando-se a técnica de estrias compostas. Após incubação a $35^{\circ} \mathrm{C} / 24 \mathrm{~h}$, as culturas foram submetidas à coloração de Gram, para avaliação do seu grau de pureza. As culturas que apresentaram mais de um tipo de bactérias (culturas impuras) no exame microscópico, foram posteriormente subcultivadas até a obtenção da cultura pura. As bactérias grampositivas (cocos, bacilos ou cocobacilos) foram cultivadas em caldo $(10 \mathrm{~mL})$ similar ao utilizado no isolamento, por 24 a 48 horas. Em seguida, a massa celular foi concentrada por centrifugação e suspensa no mesmo caldo $(3 \mathrm{~mL}) \mathrm{em}$ que foi cultivada, adicionada de glicerol 15\% (Giraffa et al., 1994). O volume total da suspensão foi distribuído em tubos Eppendorf esterilizados, e mantido sob congelamento. Para serem usadas nos experimentos, as culturas congeladas foram subcultivadas em caldo MRS, e posteriormente, semeadas em placas com ágar MRS, nas condições de incubação correspondentes, até a obtenção de culturas puras.

\subsubsection{Caracterização dos isolados}

Todos os isolados foram inicialmente submetidos à coloração de Gram, sendo avaliados quanto à forma, tamanho e arranjo celular, bem como à reação de Gram. Os isolados que, após o descongelamento, apresentaram alterações nessas características, não foram submetidos aos testes da catalase e de produção de gás a partir de glicose. 


\subsubsection{Método de Gram}

A coloração pelo método de Gram foi realizada conforme a descrição de Tortora et al. (2000).

\subsubsection{Teste da catalase}

As culturas láticas foram semeadas em placas com ágar MRS e incubadas a $35^{\circ} \mathrm{C} / 24 \mathrm{~h}$. Com o auxílio de uma alça de platina, uma massa de colônias foi depositada sobre a superfície de uma lâmina de vidro, contendo algumas gotas de peróxido de hidrogênio a 3,5\% (v/v). O teste da catalase é considerado positivo quando se observa a formação de bolhas no material sobre a lâmina (Maza et al., 1999).

\subsubsection{Teste da produção de gás a partir de glicose}

As culturas foram cultivadas em tubos de ensaio contendo caldo MRS e um tubo de Durham invertido. Após incubação a $35^{\circ} \mathrm{C} / 48 \mathrm{~h}$ foram feitas as leituras dos resultados, os quais foram considerados positivos quando ao menos 1/3 dos tubos de Durham estavam preenchidos com gás (Torriani et al., 1990). 
3.3 Comparação de médias entre contagens: bactérias totais e bactérias láticas, na água da bainha das folhas de cana-deaçúcar

Para a comparação de médias utilizou-se o teste t. 10 touceiras selecionadas, aleatoriamente, foram submetidas a estudo (Ferreira, 2000).

\subsubsection{Coleta e preparo das amostras}

Amostras foram coletadas no ano 2001, durante o mês de fevereiro, no município de Itapetinga-BA. Para cada touceira, amostras de $1 \mathrm{~mL}$ de água da bainha das folhas foram coletadas nas mesmas condições descritas no item 3.1.2.

\subsubsection{Contagem de bactérias totais}

Amostras devidamente diluídas em água peptonada $0,1 \%$ foram semeadas em ágar padrão para contagem (PCA). Os plaqueamentos foram feitos em duplicata e a técnica do "pour plate" foi empregada. Após incubação a $35^{\circ} \mathrm{C} / 48 \mathrm{~h}$ foram feitas as contagens dos microrganismos com o auxílio de contador de colônias Quebec. Os resultados das contagens foram expressos em unidade formadora de colônia (UFC/mL). 


\subsubsection{Contagem de bactérias láticas}

Amostras devidamente diluídas em água peptonada $0,1 \%$ foram semeadas em ágar MRS modificado, nas mesmas condições descritas no item 3.2. Foram contadas as colônias circundadas por halo amarelo.

\subsection{Antagonismo das bactérias láticas sobre $G$. diazotrophicus}

A ação antagônica das bactérias láticas sobre G. diazotrophicus (ATCC 49037) foi testada pelos métodos deferido e direto.

\subsubsection{Método deferido}

As culturas láticas foram cultivadas em caldo MRS. Após incubação à 35 ${ }^{\circ} \mathrm{C} / 16 \mathrm{~h}$, foram feitas as leituras da densidade óptica, em espectrofotômetro a 530 $\mathrm{nm}$. Quando necessário, as culturas láticas foram diluídas com o caldo de cultivo, utilizando-se o caldo de cultivo a fim de padronizar o inóculo a uma densidade óptica de 0,4 . Dois volumes, de $10 \mu \mathrm{L}$ cada, da cultura lática foram inoculados sobre a superfície das placas com ágar MRS, em dois pontos equidistantes entre si. Em cada placa foram semeadas duas culturas diferentes. As placas foram incubadas a $35^{\circ} \mathrm{C} / 24 \mathrm{~h}$ em aerobiose. Após incubação, essas foram cobertas com 5 $\mathrm{mL}$ de uma suspensão contendo $0,5 \mathrm{~mL}$ da cultura de $G$. diazotrophicus em caldo SYP (Caballero-Mellado \& Martinez-Romero, 1994) incubado a $35^{\circ} \mathrm{C} / 24 \mathrm{~h}$ e 4,5 $\mathrm{mL}$ de meio SYP semi-sólido (ágar 1\%). Após o crescimento sob condições aeróbicas a $35^{\circ} \mathrm{C} / 24 \mathrm{~h}$, as placas foram examinadas quanto à formação de halos de inibição. Para efeito de registro, o diâmetro externo do halo de inibição da colônia 
foi subtraído do diâmetro da colônia, correspondendo à zona de inibição (Maciel, 1998).

\subsubsection{Método direto}

As culturas láticas foram submetidas às mesmas condições de cultivo, incubação e padronização descritas no item 3.3.1. O processo de semeadura em placas das culturas láticas padronizadas, também, foi similar ao citado no método deferido. Essas placas foram cobertas com $5 \mathrm{~mL}$ de uma suspensão contendo 0,5 $\mathrm{mL}$ da cultura de $G$. diazotrophicus em caldo SYP incubado a $35^{\circ} \mathrm{C} / 24 \mathrm{~h}$ e $4,5 \mathrm{~mL}$ de meio SYP semi-sólido (ágar 1\%). Após incubação sob condições aeróbicas a $35^{\circ} \mathrm{C} / 24 \mathrm{~h}$, as placas foram examinadas quanto a formação de halos de inibição. 


\section{RESULTADOS E DISCUSSÃO}

\subsection{Contagem de bactérias láticas}

O número de bactérias láticas nas amostras de solo $_{\mathrm{s}}$ variou de $3,6 \times 10^{4}$ $\mathrm{UFC} / \mathrm{g}$ a $5,5 \times 10^{5} \mathrm{UFC} / \mathrm{g}$, sendo encontradas em números menores no meio MRS, quando comparado com o meio H (Tabela 1). Possivelmente, o melhor desenvolvimento das bactérias láticas no meio $\mathrm{H}$ seja devido à predominância de espécies heterofermentativas obrigatórias nessas amostras. Essa observação concorda com o trabalho de Kvasnikov et al. (1983) que ao pesquisarem a ocorrência de bactérias láticas na rizosfera de plantas observaram a predominância das espécies heterofermentativas Lactobacillus brevis e Lactobacillus fermentum. No meio D-MRS não foi observada a formação de colônias típicas de bactérias láticas. Dos 36 isolados obtidos a partir dessas amostras, 31 apresentaram-se em forma de bacilos, sendo isoladas bactérias em forma de cocos apenas na amostra de Itapetinga. Possivelmente, o maior valor de pH do solo (Tabela 2) nessa amostra contribuiu para o desenvolvimento de espécies do gênero Leuconostoc (bactérias em forma de cocos), que são menos tolerantes à acidez que Lactobacillus (McDonalds et al., 1990).

Nas amostras de solo $o_{p}$, o número de bactérias láticas variou de $2,5 \times 10^{5}$ UFC/g a 3,6 x $10^{5} \mathrm{UFC} / \mathrm{g}$ (Tabela 3). Os valores observados para as amostras de solo $_{s}$ e solo p $_{\mathrm{p}}$ ultrapassam aos citados por Tilbury (1975) que em amostras de solo de canaviais obteve até $5 \times 10^{3}$ células/g, sendo as amostras semeadas em meios 
específicos para espécies do gênero Leuconostoc. Dos 46 isolados obtidos a partir das amostras de solo, 27 apresentaram-se em forma de bacilos, entretanto, foram isoladas bactérias em forma de cocos em todas as amostras. Um maior número de bactérias láticas em forma de cocos foi obtido a partir dessas amostras $(58,7 \%)$, quando comparados com amostras de solo $_{\mathrm{s}}(13,9 \%)$. Outra característica observada apenas nas amostras de solo $\mathrm{p}_{\mathrm{p}}$, coletadas em Ivaí e Piracicaba, foi o desenvolvimento de colônias típicas de bactérias láticas no meio D-MRS, usado para favorecer o crescimento de bactérias láticas do gênero Leuconostoc. Esses resultados concordam com o trabalho de Mayeux, citado por Day (1992), que observou uma incidência maior de Leuconostoc no solo, em torno da planta de cana, ao nível de $45 \mathrm{~cm}$ de profundidade, sendo poucas vezes isolado ao nível de superfície. Quanto ao $\mathrm{pH}$, as amostras de solo ${ }_{\mathrm{p}}$ apresentaram valores similares aos observados para as amostras de solo $_{s}$ (Tabela 2). Portanto, as diferenças observadas no número de bactérias láticas (UFC/g) entre as amostras de solo $_{\mathrm{s}} \mathrm{e}$ solo $_{\mathrm{p}}$ não podem ser atribuídas às diferenças de $\mathrm{pH}$.

Tabela 1 - Número de bactérias láticas (UFC/g) nas amostras de solo em profundidade de 0 a $20 \mathrm{~cm}$ ( $\left(\right.$ solo $_{\mathrm{s}}$ ), coletadas nos municípios de IvaíPR, Piracicaba-SP e Itapetinga-BA.

\begin{tabular}{cccc}
\hline & \multicolumn{3}{c}{$\begin{array}{c}\text { Número de Bactérias Láticas } \\
\text { (UFC/g) }\end{array}$} \\
\cline { 2 - 4 } Amostras dos & MRS & D-MRS & $\mathrm{H}$ \\
Municípios & & & \\
\hline Ivaí-PR & $2,5 \times 10^{5}$ & - & $3,6 \times 10^{5}$ \\
Piracicaba-SP & $3,6 \times 10^{4}$ & - & $2,5 \times 10^{5}$ \\
Itapetinga-BA & $4,9 \times 10^{4}$ & - & $5,5 \times 10^{5}$ \\
\hline
\end{tabular}


Tabela 2 - Valores de $\mathrm{pH}$ para as amostras de solo $_{\mathrm{s}}$ e solo $_{\mathrm{p}}$, coletadas nos municípios de Ivaí-PR, Piracicaba-SP e Itapetinga-BA.

\begin{tabular}{ccc}
\hline & \multicolumn{2}{c}{$\mathrm{pH}$} \\
\cline { 2 - 3 } Amostras dos & solo $_{\mathrm{s}}$ & Solo $_{\mathrm{p}}$ \\
Municípios & & \\
\hline Ivaí-PR & 4,5 & 4,5 \\
Piracicaba-SP & 5,4 & 5,5 \\
Itapetinga-BA & 5,9 & 6,0 \\
\hline
\end{tabular}

Tabela 3 - Número de bactérias láticas (UFC/g) nas amostras de solo em profundidade de 20 a $40 \mathrm{~cm}$ ( solo $_{\mathrm{p}}$ ), coletadas nos municípios de Ivaí-PR, Piracicaba-SP e Itapetinga-BA.

\begin{tabular}{cccc}
\hline & \multicolumn{3}{c}{$\begin{array}{c}\text { Número de Bactérias Láticas } \\
\text { (UFC/g) }\end{array}$} \\
\cline { 2 - 4 } Amostras dos & MRS & D-MRS & $\mathrm{H}$ \\
Municípios & & & \\
\hline Ivaí-PR & $3,6 \times 10^{5}$ & $2,5 \times 10^{5}$ & $2,5 \times 10^{5}$ \\
Piracicaba-SP & $3,6 \times 10^{5}$ & $3,6 \times 10^{5}$ & $3,6 \times 10^{5}$ \\
Itapetinga - BA & $3,6 \times 10^{5}$ & - & $3,6 \times 10^{5}$ \\
\hline
\end{tabular}

O número de bactérias láticas nas amostras de água da bainha das folhas de cana-de-açúcar variou de $2,5 \times 10^{5}$ a $6,4 \times 10^{5} \mathrm{UFC} / \mathrm{mL}$ (Tabela 4). Duncan \& Colmer (1964), também, encontraram valores elevados de populações bacterianas em amostras semelhantes, na ordem de $10^{6} \mathrm{UFC} / \mathrm{mL}$. Apesar dos baixos níveis de nutrientes encontrados nos filmes de água sobre superfícies de inserção de folhas, a água da bainha tem suportado bom crescimento de bactérias. Possivelmente, a maior capacidade das bactérias de absorção de nutrientes em soluções diluídas, em relação aos fungos (Blakeman \& Fokkema, 1982), a presença de carboidratos fermentáveis, em concentrações de 0,08 a $30 \mathrm{mg} / \mathrm{L}$ (Mayeux, citado por Duncan \& Colmer, 1964) e os valores de pH relativamente 
baixos na água da bainha (Duncan \& Colmer, 1964) sejam os principais responsáveis pelos elevados números de bactérias láticas encontrados nessas amostras. As bactérias láticas presentes nas amostras de água da bainha das folhas de cana-de-açúcar coletadas em Piracicaba e Itapetinga apresentaram bom crescimento no meio D-MRS. Na amostra coletada em Ivaí, apesar da ocorrência de bactérias em forma de cocos nos meios MRS e $\mathrm{H}$, não foi observado crescimento no meio D-MRS. Dos isolados obtidos a partir dessas amostras ocorreram bactérias em forma de cocos e cocobacilos.

Tabela 4 - Número de bactérias láticas (UFC/mL) nas amostras de água da bainha das folhas de cana-de-açúcar, coletadas nos municípios de Ivaí-PR, Piracicaba-SP e Itapetinga-BA.

\begin{tabular}{cccc}
\hline & \multicolumn{3}{c}{$\begin{array}{c}\text { Número de Bactérias Láticas } \\
\text { (UFC/mL) }\end{array}$} \\
\cline { 2 - 4 } Amostras dos & MRS & D-MRS & $\mathrm{H}$ \\
Municípios & & & \\
\hline Ivaí-PR & $3,6 \times 10^{5}$ & - & $3,6 \times 10^{5}$ \\
Piracicaba-SP & $2,5 \times 10^{5}$ & $2,5 \times 10^{5}$ & $2,5 \times 10^{5}$ \\
Itapetinga-BA & $3,6 \times 10^{5}$ & $6,4 \times 10^{5}$ & $3,6 \times 10^{5}$ \\
\hline
\end{tabular}

O número de bactérias láticas nas amostras das superícies dos colmos de cana-de-açúcar variou de $3,6 \times 10^{3}$ a $2,5 \times 10^{5} \mathrm{UFC} / \mathrm{mL}$ ou $1,1 \times 10^{2}$ a $1,1 \times 10^{4}$ $\mathrm{UFC} / \mathrm{cm}^{2}$ (Tabelas 5 e 6). Na amostra coletada em Ivaí, números elevados foram observados, na ordem de $10^{5} \mathrm{UFC} / \mathrm{mL}$, quando comparados com os números obtidos a partir de amostras coletadas em Piracicaba e Itapetinga. Possivelmente, essa variação foi devida aos diferentes intervalos de tempo entre coleta e análise da amostra em laboratório, que foi 3 vezes maior em Ivaí. Dos 
isolados obtidos a partir dessas amostras ocorreram bactérias em forma de cocos e cocobacilos.

Bactérias láticas, em forma de bacilos, não foram observadas nas amostras de água da bainha e na superfície dos colmos, tendo sido isoladas apenas bactérias em forma de cocos e cocobacilos. Possivelmente, a melhor adaptação aos materiais de plantas e a menor sensibilidade às altas tensões de oxigênio (Holzapfel \& Schillinger, 1992) podem ter favorecido o crescimento de espécies do gênero Leuconostoc nessas amostras. Entretanto, deve ser considerado que algumas espécies de Lactobacillus formam bacilos muito curtos, podendo ser confundidos com Leuconostoc e no caso de algumas espécies de lactobacilos heterofermentativos, essa diferenciação só poderá ser feita através dos testes de produção de amônia a partir de arginina e de formação de enantiômeros do ácido lático a partir de glicose (Hammes et al., 1992).

Tabela 5 - Número de bactérias láticas (UFC/mL) nas amostras das superfícies dos colmos de cana-de-açúcar, coletadas nos municípios de Ivaí$\mathrm{PR}$, Piracicaba-SP e Itapetinga-BA.

\begin{tabular}{|c|c|c|c|}
\hline \multirow[b]{2}{*}{$\begin{array}{l}\text { Amostras dos } \\
\text { Municípios }\end{array}$} & \multicolumn{3}{|c|}{$\begin{array}{l}\text { Número de Bactérias Láticas } \\
\text { (UFC/mL) }\end{array}$} \\
\hline & MRS & D-MRS & $\mathrm{H}$ \\
\hline Ivaí-PR & $2,5 \times 10^{5}$ & $2,5 \times 10^{5}$ & $2,5 \times 10^{5}$ \\
\hline $\mathrm{Pi}$ & - & $3,6 \times 10^{3}$ & - \\
\hline Itapetinga-BA & $3,6 \times 10^{3}$ & - & - \\
\hline
\end{tabular}


Tabela 6 - Número de bactérias láticas $\left(\mathrm{UFC} / \mathrm{cm}^{2}\right.$ ) nas amostras das superficies dos colmos de cana-de-açúcar, coletadas nos municípios de IvaíPR, Piracicaba-SP e Itapetinga-BA.

\begin{tabular}{cccc}
\hline & \multicolumn{3}{c}{$\begin{array}{c}\text { Número de Bactérias Láticas } \\
\left(\mathrm{UFC} / \mathrm{cm}^{2}\right)\end{array}$} \\
\cline { 2 - 4 } $\begin{array}{c}\text { Amostras dos } \\
\text { Municípios }\end{array}$ & MRS & D-MRS & $\mathrm{H}$ \\
\hline Ivaí-PR & $1,1 \times 10^{4}$ & $1,1 \times 10^{4}$ & $1,1 \times 10^{4}$ \\
Piracicaba-SP & - & $1,1 \times 10^{2}$ & - \\
Itapetinga-BA & $2,7 \times 10^{2}$ & - & - \\
\hline
\end{tabular}

Em geral, o número de bactérias láticas foi maior nas amostras de solo e de água da bainha das folhas (na ordem de $10^{5} \mathrm{UFC} / \mathrm{g}$ ), quando comparado com amostras das superfícies dos colmos de cana-de-açúcar (na ordem de $10^{3}$ $\mathrm{UFC} / \mathrm{mL}$ ). Essa redução no número de bactérias láticas pode ser devida a exposição direta dos colmos à atmosfera e à radiação solar, principalmente, nos estádios iniciais de desenvolvimento do canavial, quando a área foliar é menor (Angelocci et al., 1996).

\subsection{Isolamento de bactérias láticas}

Foram isoladas 156 colônias típicas de bactérias láticas nos meios MRS, D-MRS e $\mathrm{H}$, a partir das amostras coletadas nas municípios de Ivaí-PR, Piracicaba-SP e Itapetinga-BA. 47 isolados foram obtidos a partir das amostras de água da bainha das folhas, enquanto apenas 27 foram obtidos a partir de amostras das superficies dos colmos (Tabelas 7, 8 e 9). Os isolados gram-positivos foram mantidos no experimento. 
Tabela 7 - Número de isolados nos diferentes meios de cultura, para as amostras coletadas no município de Ivaí-PR.

\begin{tabular}{ccccc}
\hline & \multicolumn{5}{c}{ Número de Isolados } \\
\cline { 2 - 5 } Amostras & MRS & D-MRS & H & Total \\
\hline Solo $_{\mathrm{s}}$ & 5 & - & 6 & 11 \\
Solo $_{\mathrm{p}}$ & 6 & 5 & 5 & 16 \\
Água da bainha & 6 & - & 6 & 12 \\
Superficie dos colmos & 5 & 5 & 5 & 15 \\
\hline Total & 22 & 10 & 22 & 54 \\
\hline
\end{tabular}

Tabela 8 - Número de isolados nos diferentes meios de cultura, para as amostras coletadas no município de Piracicaba-SP.

\begin{tabular}{ccccc}
\hline & \multicolumn{4}{c}{ Número de Isolados } \\
\cline { 2 - 5 } Amostras & MRS & D-MRS & H & Total \\
\hline Solo $_{\mathrm{s}}$ & 6 & - & 5 & 11 \\
Solo $_{\mathrm{p}}$ & 6 & 6 & 6 & 18 \\
Água da bainha & 5 & 5 & 5 & 15 \\
Superficie dos colmos & - & 6 & - & 6 \\
\hline Total & 17 & 17 & 16 & 50 \\
\hline
\end{tabular}

Tabela 9 - Número de isolados nos diferentes meios de cultura, para as amostras coletadas no município de Itapetinga-BA.

\begin{tabular}{ccccc}
\hline & \multicolumn{4}{c}{ Número de Isolados } \\
\cline { 2 - 5 } Amostras & MRS & D-MRS & H & Total \\
\hline Solo $_{\mathrm{s}}$ & 7 & - & 7 & 14 \\
Solo $_{\mathrm{p}}$ & 6 & - & 6 & 12 \\
Água da bainha & 6 & 8 & 6 & 20 \\
Superficie dos colmos & 6 & - & - & 6 \\
\hline Total & 25 & 8 & 19 & 52 \\
\hline
\end{tabular}




\subsection{Caracterização dos isolados}

Dos 156 isolados submetidos à coloração de Gram, apenas 74 apresentaram características morfológicas similares às observadas durante o isolamento das bactérias láticas, sendo testados quanto à atividade de catalase e de produção de gás a partir de glicose.

\subsubsection{Método de Gram}

Colônias bem isoladas no ágar MRS foram submetidas à coloração de Gram. As culturas impuras foram reisoladas neste meio até a obtenção de culturas puras. Em todas as amostras de solo $_{\mathrm{s}}$ e solo $\mathrm{p}$ não foi possível recuperar os isolados em forma de bacilos, obtidos durante o isolamento das culturas láticas. Entretanto, foram recuperados todos os isolados em forma de cocos obtidos a partir dessas amostras. $\mathrm{O}$ tempo de permanência das culturas láticas congeladas em "freezer" foi de dois meses para os isolados obtidos a partir de amostras coletadas em Itapetinga e de dez meses para os de Ivaí e Piracicaba. Provavelmente, o método de conservação (congelamento) utilizado não foi o mais adequado às culturas láticas em forma de bacilos isoladas nesses experimentos.

\subsubsection{Teste da catalase e da produção de gás a partir de glicose}

Os 74 isolados obtidos a partir das amostras de água da bainha das folhas e das superficies dos colmos de cana-de-açúcar deram resultados negativos nos testes da catalase e da produção de gás a partir de glicose. 
Todos os isolados testados apresentaram-se em forma de cocos ou cocobacilos, podendo pertencer ao gênero Leuconostoc. As bactérias desse gênero são capazes de produzir gás a partir de glicose (Holzapfel \& Schillinger, 1992). Portanto, esperava-se que alguns isolados dessem resultados positivos para o teste de produção de gás a partir de glicose. Entretanto, algumas espécies de lactobacilos podem apresentar-se em forma de cocobacilos (Kandler $\&$ Weiss, 1986). Considerando que as espécies de lactobacilos homofermentativos não produzem gás (Hammes et al., 1992) e que algumas espécies de lactobacilos heterofermentativos não produzem gás a partir de glicose (Tanasupawat et al., 1992), os isolados obtidos nesses experimentos podem pertencer ao gênero Lactobacillus.

\subsection{Comparação de médias entre contagens: bactérias totais e bactérias láticas, na água da bainha das folhas de cana-de açúcar}

As médias aritméticas das contagens de bactérias totais e de bactérias láticas nas amostras de água da bainha das folhas de cana-de-açúcar foram de $11,7 \times 10^{5}$ e $1,19 \times 10^{5} \mathrm{UFC} / \mathrm{mL}$, respectivamente (Tabela 10). Esses resultados permitem concluir que o número de bactérias láticas encontradas nessas amostras representa, aproximadamente, $10 \%$ da população total de bactérias. Quando as bactérias láticas foram isoladas das superfícies das folhas de diversas plantas, números de 10 a $10^{3} \mathrm{UFC} / \mathrm{mL}$ foram encontrados, representando 0,01 a $1 \%$ da população total de bactérias (Hammes et al., 1992). No caldo de cana, obtido a partir de colmos recém-colhidos, o número de bactérias láticas variou de $5 \times 10^{4} \mathrm{a}$ $5 \times 10^{5} \mathrm{UFC} / \mathrm{mL}$ (Tilbury, 1975). Portanto, verifica-se que o número de bactérias 
láticas encontradas na água da bainha das folhas é similar aos valores encontrados no caldo de cana, obtido logo após a colheita dos colmos.

Quanto à contagem de bactérias totais, os valores encontrados nesse experimento concordam com o trabalho de Duncan \& Colmer (1964), os quais obtiveram contagens na ordem de $10^{6} \mathrm{UFC} / \mathrm{mL}$.

Os valores do coeficiente de variação calculados para ambas as contagens foram baixos, indicando haver pouca variação entre as amostras, dentro de cada tratamento. $\mathrm{O}$ teste $\mathrm{t}$ demonstrou que há diferença significativa (alfa igual a $1 \%$ ) entre as médias das contagens de bactérias totais e de bactérias láticas.

Tabela 10 - Resultados estatísticos das contagens de bactérias totais e de bactérias láticas (UFC/mL) nas amostras de água da bainha das folhas de cana-de-açúcar, coletadas no município de Itapetinga-BA.

\begin{tabular}{ccc}
\hline $\begin{array}{c}\text { Parâmetros } \\
\text { Estatísticos Avaliados }\end{array}$ & $\begin{array}{c}\text { Contagem de } \\
\text { Bactérias Totais }\end{array}$ & $\begin{array}{c}\text { Contagem de Bactérias } \\
\text { Láticas }\end{array}$ \\
\hline Média Aritmética & $11,7 \times 10^{5}$ & $1,19 \times 10^{5}$ \\
Desvio-Padrão & $6,5 \times 10^{2}$ & $0,73 \times 10^{2}$ \\
Variância & $42,3 \times 10^{4}$ & $0,54 \times 10^{4}$ \\
Coeficiente de & 0,056 & 0,061 \\
Variação & & \\
Mínimo & $10^{6}$ & $10^{5}$ \\
Máximo & $1,5 \times 10^{6}$ & $1,6 \times 10^{5}$ \\
\hline
\end{tabular}

\subsection{Antagonismo das bactérias láticas sobre $G$. diazotrophicus}

Dos 74 isolados obtidos a partir das amostras de água da bainha das folhas e das superfícies dos colmos de cana-de-açúcar, 58 apresentaram zonas de 
inibição sobre $G$. diazotrophicus, as quais variaram de 3 a $10 \mathrm{~mm}$. 11 isolados formaram zonas de inibição pelos dois métodos usados e 47 apresentaram zonas de inibição apenas por um dos dois métodos. Zonas de inibição maiores foram observadas pelo método deferido (Tabelas 11, 12 e 13). Esse método, amplamente utilizado na pesquisa de bactérias láticas produtoras de bacteriocinas (Giraffa et al., 1994; Lewus et al., 1991; Schillinger \& Lucke, 1989), requer um período de incubação para as culturas láticas. Portanto, o maior número de isolados com atividade antagônica, bem como as zonas de inibição maiores observadas pelo método deferido, podem ser devidos ao acúmulo de produtos finais do metabolismo das bactérias láticas tais como ácidos orgânicos, diacetil e peróxido de hidrogênio, entre outros (Earnshaw, 1992). No método direto, onde as bactérias láticas crescem simultaneamente com $G$. diazotrophicus, o menor efeito inibidor observado pode ser devido à baixa competição entre as duas culturas de bactérias. É possível que a utilização do lactato e acetato por $G$. diazotrophicus, como fontes de carbono (Franke et al., 1999), possa ter contribuído para a redução da competição por nutrientes.

Dos 27 isolados obtidos a partir das amostras coletadas em Ivaí, 21 apresentaram zonas de inibição. 11 isolados apresentaram zonas de inibição pelos dois métodos usados, sendo todos obtidos no meio MRS. 10 isolados apresentaram zonas de inibição apenas pelo método direto, sendo todos obtidos no meio $\mathrm{H}$ (Tabela 11). Portanto, observa-se um menor poder de inibição para os isolados obtidos no meio $\mathrm{H}$ (para lactobacilos heterofermentativos obrigatórios) em relação ao meio MRS (para lactobacilos acidófilos). Considerando que na fermentação homolática mais de $85 \%$ do produto final é ácido lático e que na fermentação heterolática esse valor é de apenas 50\% (Hammes et al., 1992), essa diferença pode ser devida a maior produção e acúmulo de ácido lático pelos isolados obtidos no meio MRS. Dos 6 isolados, que não apresentaram zonas de inibição, 5 foram obtidos a partir da amostra da superfície dos colmos no meio D- 
MRS, sendo 1 obtido a partir da amostra de água da bainha das folhas no meio $\mathrm{H}$. Não se observou diferença entre as duas amostras em relação à atividade antagônica dos isolados. As zonas de inibição variaram de 5 a 8 mm (Tabela 11).

Tabela 11 - Zonas de inibição $(\mathrm{mm})$ produzidas por bactérias láticas isoladas sobre $G$. diazotrophicus nos meios MRS, D-MRS e $\mathrm{H}$, para as amostras coletadas no município de Ivaí-PR .

\begin{tabular}{cccccccc}
\hline & \multicolumn{5}{c}{ Zonas de inibição (mm) } \\
\cline { 2 - 7 } Amostras/Isolados & \multicolumn{3}{c}{ Método Direto } & \multicolumn{3}{c}{ Método Deferido } \\
\hline Água da bainha & MRS & D-MRS & H & MRS & D-MRS & H \\
\hline 1 & 7 & - & 6 & 5 & - & 0 \\
2 & 7 & - & 6 & 5 & - & 0 \\
3 & 5 & - & 5 & 8 & - & 0 \\
4 & 7 & - & 5 & 8 & - & 0 \\
5 & 5 & - & 5 & 8 & - & 0 \\
6 & 6 & - & 5 & 0 & - & 0 \\
Superfície dos colmos & & & & & & \\
\hline 1 & 8 & 0 & 0 & 5 & 0 & 0 \\
2 & 8 & 0 & 5 & 5 & 0 & 0 \\
3 & 5 & 0 & 5 & 6 & 0 & 0 \\
4 & 6 & 0 & 5 & 6 & 0 & 0 \\
5 & 5 & 0 & 5 & 8 & 0 & 8 \\
\hline
\end{tabular}

(-) não houve isolado no meio;

(0) isolado testado não apresenta zona de inibição.

Dos 21 isolados obtidos a partir das amostras coletadas em Piracicaba, 20 apresentaram zonas de inibição pelo método deferido e apenas 1 não apresentou zonas de inibição. Não foram observadas diferenças na atividade antagônica dos isolados em relação aos meios usados e às duas amostras avaliadas. As zonas de inibição variaram de 3 a $10 \mathrm{~mm}$ (Tabela 12). 
Tabela 12 - Zonas de inibição $(\mathrm{mm})$ produzidas por bactérias láticas isoladas sobre $G$. diazotrophicus nos meios MRS, D-MRS e $\mathrm{H}$, para as amostras coletadas no município de Piracicaba-SP.

\begin{tabular}{cccccccc}
\hline & \multicolumn{5}{c}{ Zonas de inibição (mm) } \\
\cline { 2 - 7 } Amostras/Isolados & \multicolumn{3}{c}{ Método Direto } & \multicolumn{3}{c}{ Método Deferido } \\
\hline Água da bainha & MRS & D-MRS & H & MRS & D-MRS & H \\
\hline 1 & 0 & 0 & 0 & 4 & 8 & 4 \\
2 & 0 & 0 & 0 & 3 & 10 & 0 \\
3 & 0 & 0 & 0 & 4 & 9 & 5 \\
4 & 0 & 0 & 0 & 4 & 10 & 5 \\
5 & 0 & 0 & 0 & 4 & 8 & 4 \\
Superficie dos colmos & & & & & & \\
\hline 1 & - & 0 & - & - & 4 & - \\
2 & - & 0 & - & - & 4 & - \\
3 & - & 0 & - & - & 5 & - \\
4 & - & 0 & - & - & 5 & - \\
5 & - & 0 & - & - & 4 & - \\
6 & - & & - & - & 4 & - \\
\hline
\end{tabular}

$(-)$ não houve isolado no meio;

(0) isolado testado não apresenta zona de inibição.

Dos 26 isolados obtidos a partir das amostras coletadas em Itapetinga, 17 apresentaram zonas de inibição, sendo todas observadas pelo método deferido. Um maior número de isolados com atividade antagônica foi obtido no meio DMRS (8)., As zonas de inibição variaram de 6 a 10 mm (Tabela 13). 
Tabela 13 - Zonas de inibição $(\mathrm{mm})$ produzidas por bactérias láticas isoladas sobre G. diazotrophicus nos meios MRS, D-MRS e $\mathrm{H}$, para as amostras coletadas no município de Itapetinga-BA.

\begin{tabular}{cccccccc}
\hline & \multicolumn{5}{c}{ Zonas de inibição (mm) } \\
\cline { 2 - 7 } Amostras/Isolados & \multicolumn{5}{c}{ Método Direto } & \multicolumn{3}{c}{ Método Deferido } \\
\hline Água da bainha & MRS & D-MRS & H & MRS & D-MRS & H \\
\hline 1 & 0 & 0 & 0 & 0 & 7 & 0 \\
2 & 0 & 0 & 0 & 0 & 8 & 10 \\
3 & 0 & 0 & 0 & 0 & 9 & 0 \\
4 & 0 & 0 & 0 & 0 & 9 & 10 \\
5 & 0 & 0 & 0 & 8 & 9 & 10 \\
6 & 0 & 0 & 0 & 0 & 7 & 10 \\
7 & - & 0 & - & - & 6 & - \\
8 & - & 0 & - & - & 10 & - \\
Superfície dos colmos & & & & & & \\
\hline 1 & 0 & - & - & 7 & - & - \\
2 & 0 & - & - & 8 & - & - \\
3 & 0 & - & - & 0 & - & - \\
4 & 0 & - & - & 7 & - & - \\
5 & 0 & - & - & 0 & - & - \\
6 & 0 & - & - & 8 & - & - \\
\hline
\end{tabular}

(-) não houve isolado no meio;

(0) isolado testado não apresenta zona de inibição.

De forma contrária ao município de Ivaí, os isolados obtidos a partir das amostras coletadas em Piracicaba e Itapetinga não apresentaram zonas de inibição pelo método direto. Possivelmente, mecanismos de inibição diferentes estão envolvidos nos dois métodos usados. No método direto, as culturas láticas estão no estádio inicial de desenvolvimento, enquanto que no método deferido, essas culturas apresentam crescimento acentuado com acúmulo de diversas substâncias inibidoras. Dos 11 isolados que apresentaram zonas de inibição pelos dois métodos, 6 apresentaram zonas de inibição maiores pelo método deferido, 4 pelo método direto e apenas 1 apresentou valores similares para os dois métodos. 
Foram observadas diferenças de até $3 \mathrm{~mm}$ no tamanho dos zonas de inibição entre os dois métodos (Figuras 1 e 2). No método deferido, possivelmente, o acúmulo de substâncias inibidoras justificaria tal diferença. No método direto, a ocorrência de zonas de inibição maiores pode ser devida a degradação do(s) composto(s) inibidor(es) após um determinado período de tempo. É o que acontece, por exemplo, com o peróxido de hidrogênio na presença de algumas enzimas tais como catalase e NADH peroxidase, entre outras. Essas degradam o peróxido e, conseqüentemente, eliminam sua ação antimicrobiana (Ribeiro, 1995). É possível que a síntese da enzima catalase por $G$. diazotrophicus, após um determinado período de tempo, esteja envolvida na redução no diâmetro dos halos de inibição pelo método deferido, em relação ao método direto. Entretanto, deve-se considerar que houve apenas uma redução no diâmetro dos halos, indicando que outro(s) mecanismo(s) de inibição pode(m) estar envolvido(s). Outros fatores a serem considerados são a concentração e o grau de difusão do(s) composto(s) envolvido(s) na inibição. Para a inibição de Salmonella sp. por algumas espécies de lactobacilos são necessários $2,5 \mu \mathrm{g} / \mathrm{mL}$ de peróxido de hidrogênio (Ribeiro, 1995). Entretanto, a inibição de bactérias gram-negativas por diacetil só é observada em concentrações elevadas, acima de $200 \mu \mathrm{g} / \mathrm{mL}$ (Jay, 1982). Visser \& Holzapfel (1992), ao pesquisarem o grau de difusão dos ácidos lático e acético, verificaram que esse último apresentou maior difusão no ágar NBY, promovendo maior redução no $\mathrm{pH}$ a distâncias de até $10 \mathrm{~mm}$. 


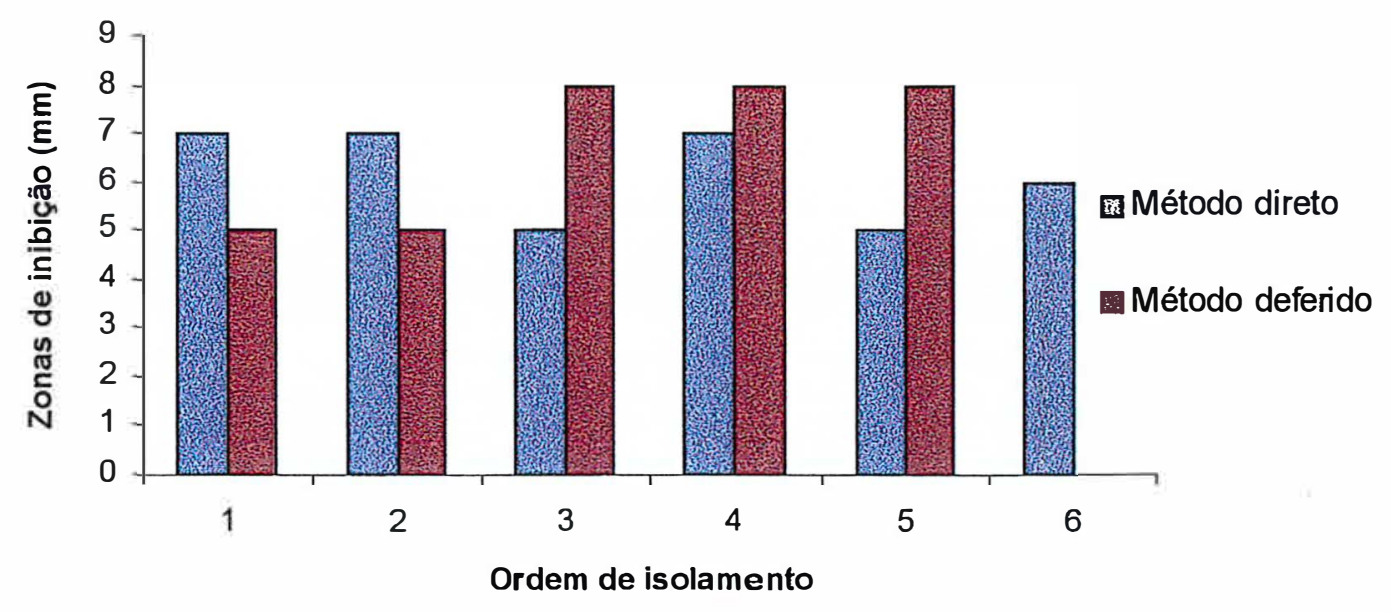

Figura 1 - Zonas de inibição $(\mathrm{mm})$ produzidas por bactérias láticas isoladas sobre G. diazotrophicus no meio MRS, para a amostra de água da bainha coletada no município de Ivaí-PR.

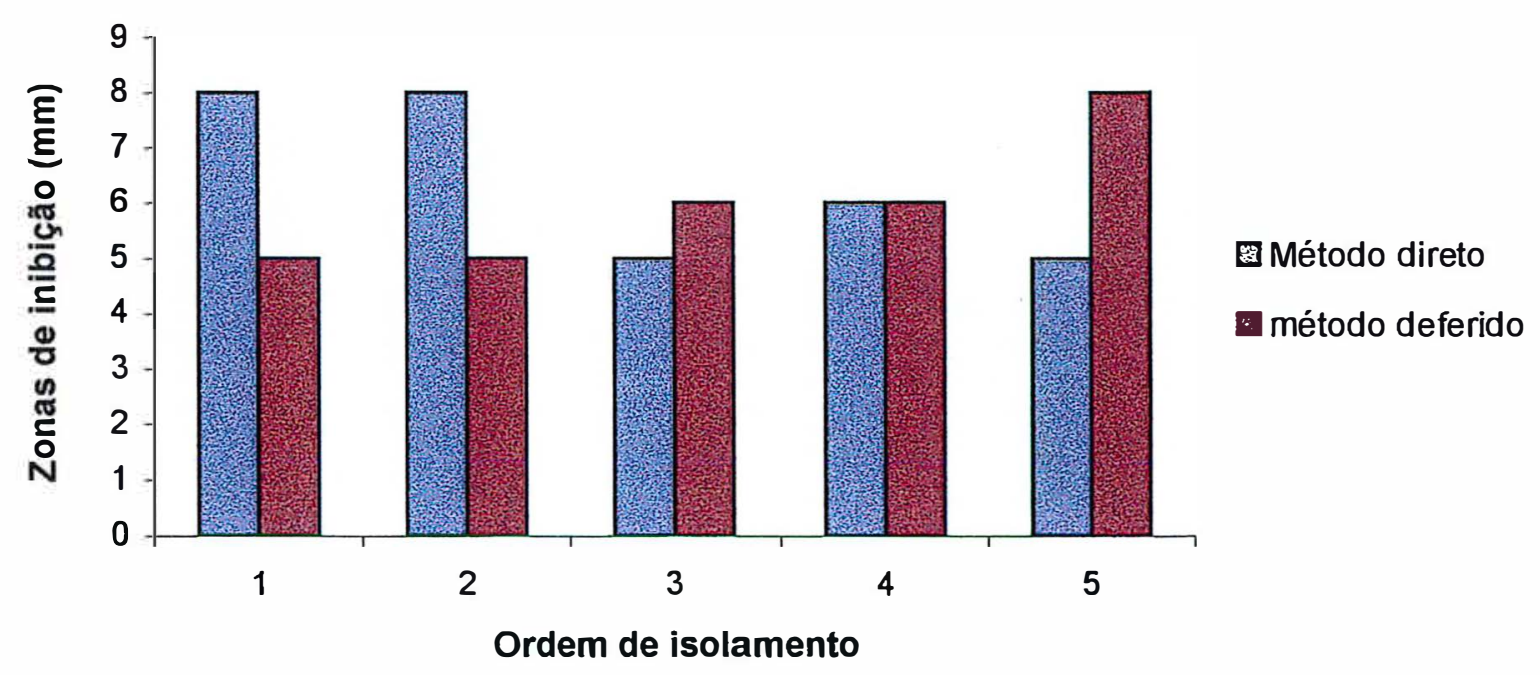

Figura 2 - Zonas de inibição (mm) produzidas por bactérias láticas isoladas sobre G. diazotrophicus no meio MRS, para a amostra da superfície dos colmos coletada no município de Ivaí-PR. 
Quanto às zonas de inibição produzidas pelos isolados sobre $G$. diazotrophicus, verificou-se para as amostras coletadas em Ivaí que 36,4\% dos isolados apresentaram zonas de inibição de até $5 \mathrm{~mm}$ pelo método deferido, enquanto $57,2 \%$ dos isolados apresentaram zonas de inibição de $5 \mathrm{~mm}$ pelo método direto (Figuras 3 e 4). Nas amostras de Piracicaba, zonas de inibição de até $5 \mathrm{~mm}$ foram produzidas por $75 \%$ dos isolados (Figura 5). Entretanto, todos os isolados obtidos a partir das amostras coletadas em Itapetinga apresentaram zonas de inibição maiores que $5 \mathrm{~mm}$ (Figura 6).

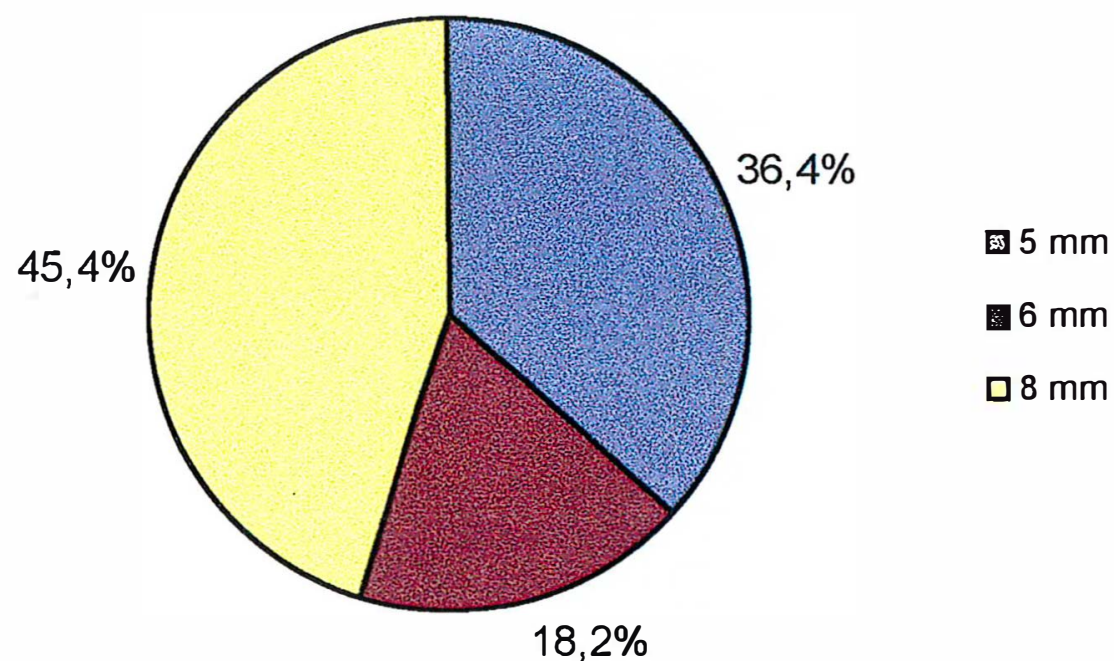

Figura 3 - Distribuição das zonas de inibição ( $\mathrm{mm}$ ) observadas pelo método deferido, para os isolados obtidos a partir das amostras coletadas em Ivaí - PR. 


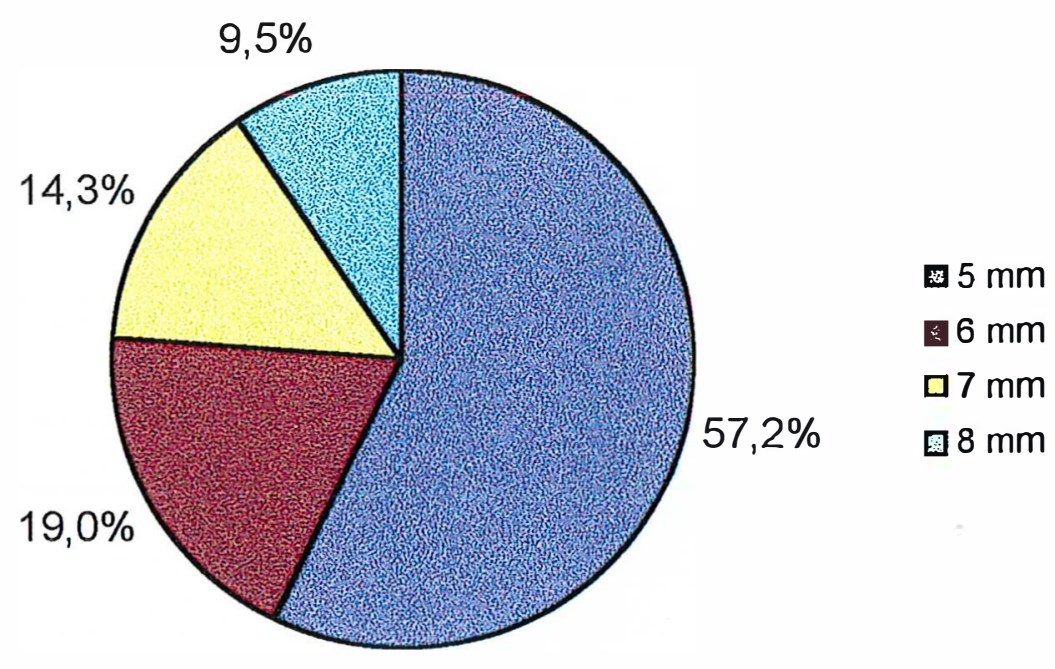

Figura 4 - Distribuição das zonas de inibição $(\mathrm{mm})$ observadas pelo método direto, para os isolados obtidos a partir das amostras coletadas em Ivaí - PR.

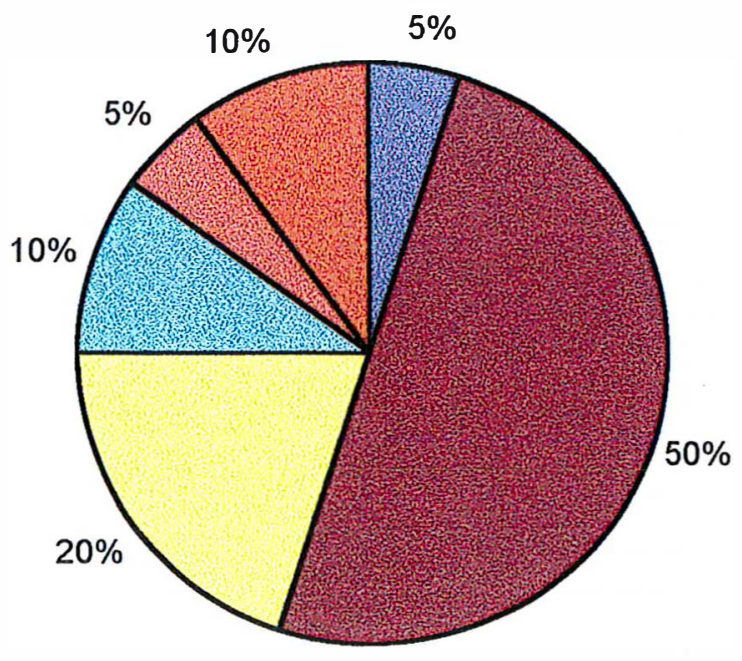

娄 $3 \mathrm{~mm}$

$4 \mathrm{~mm}$

$\square 5 \mathrm{~mm}$

圆 $8 \mathrm{~mm}$

圆 $9 \mathrm{~mm}$

因 $10 \mathrm{~mm}$

Figura 5 - Distribuição das zonas de inibição $(\mathrm{mm})$ observadas pelo método deferido, para os isolados obtidos a partir das amostras coletadas em Piracicaba-SP. 


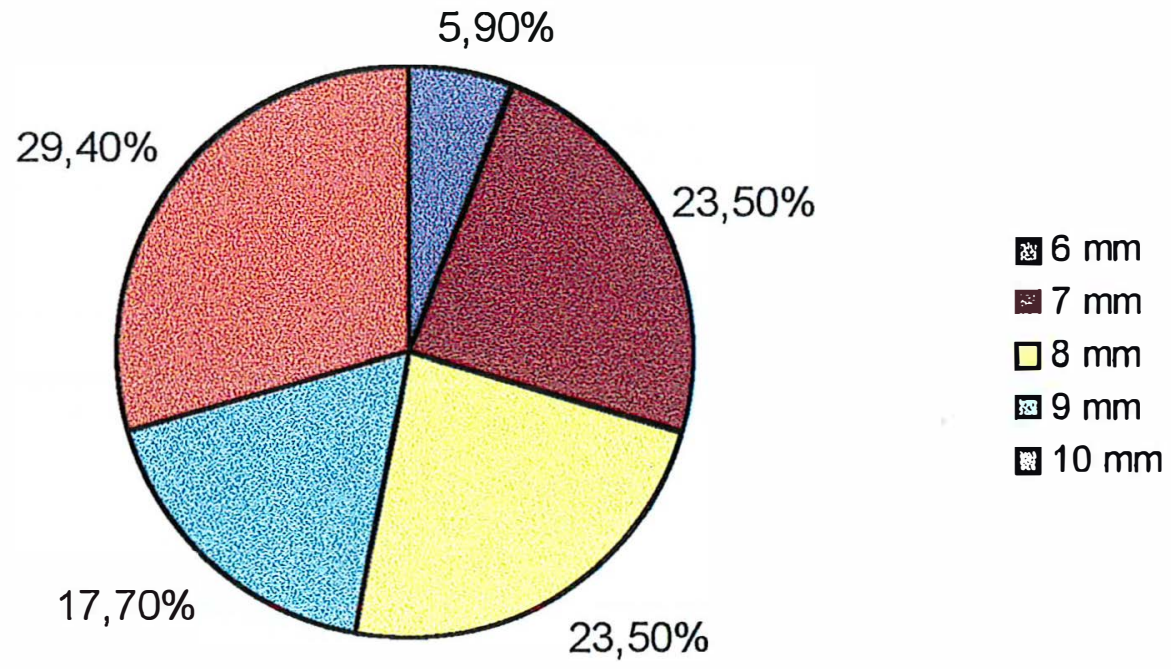

Figura 6 - Distribuição das zonas de inibição (mm) observadas pelo método deferido, para os isolados obtidos a partir das amostras coletadas em Itapetinga - BA.

A verificação do espectro de inibição, com base na medida das zonas de inibição, varia de acordo com os critérios de avaliação adotados por cada pesquisador. Quando o método deferido foi utilizado em condições onde o efeito inibitório dos ácidos orgânicos e do peróxido de hidrogênio foi eliminado, considerou-se haver uma inibição forte quando as zonas de inibição foram maiores que $10 \mathrm{~mm}$ (Lewus et al., 1991; Olsen et al., 1995). Quando o efeito antagônico desses compostos não foi eliminado, observaram-se zonas de inibição com até $26 \mathrm{~mm}$ (Maciel, 1998). Para o método direto, as zonas de inibição variaram de 15 a $30 \mathrm{~mm}$, quando foi avaliada a ação antimicrobiana de todos os metabólitos produzidos pelos isolados (Raccach et al., 1989; Visser \& Holzapfel, 
1992). Portanto, verifica-se que o efeito inibidor dos isolados sobre $G$. diazotrophicus é pequeno, quando comparado com a literatura citada.

Neste trabalho foram avaliadas as interações negativas (competição e antagonismo) entre bactérias láticas e $G$. diazotrophicus, entretanto, deve-se considerar que interações positivas entre essas culturas podem ocorrer. Por exemplo, os ácidos orgânicos produzidos pelas bactérias láticas podem ser utilizados como fonte de carbono por $G$. diazotrophicus. Por outro lado, $G$. diazotrophicus produz compostos nitrogenados que são transferidos para a planta de cana-de-açúcar, podendo ser utilizados, posteriormente, por bactérias láticas, as quais apresentam exigências nutricionais complexas. Vale ressaltar que esses microrganismos ocupam habitates diferentes, porém, localizados em áreas muito próximas, sendo possivel ocorrer tais interações.

$\mathrm{Na}$ água da bainha das folhas de cana-de-açúcar, as bactérias láticas representam apenas $10 \%$ da população de bactérias totais e, nesse caso, as interações estarão envolvendo uma diversidade de microrganismos. Ao utilizar o ácido lático produzido por bactérias láticas, G. diazotrophicus estará removendo uma substância inibitória para muitas populações bacterianas. Por outro lado, ao utilizarem o oxigênio, as bactérias aeróbias favorecem o crescimento das bactérias láticas, que preferem condições microaerófilas.

Quando ocorre a desestabilização da microbiota normal, as plantas tornam-se mais susceptíveis às invasões por microrganismos patogênicos oportunistas. É possível que a presença de bactérias láticas na planta de cana-deaçúcar, possa estar relacionada ao efeito inibitório sobre algumas bactérias fitopatogênicas, reduzindo assim os riscos de infecções na planta. 


\section{CONCLUSÕES}

Verificou-se a ocorrência de bactérias láticas no solo de canaviais, na água da bainha das folhas e na superficie dos colmos de cana-de-açúcar.

$\mathrm{O}$ número de bactérias láticas nas amostras de água da bainha das folhas, coletadas no município de Itapetinga, em fevereiro de 2001, representa, aproximadamente, $10 \%$ da população total de bactérias.

Das 74 colônias de bactérias láticas isoladas a partir das amostras de água da bainha das folhas e da superfície dos colmos de cana-de-açúcar, 58 apresentaram ação antagônica sobre $G$. diazotrophicus. O efeito inibidor desses isolados pode ser considerado fraco, pois $78 \%$ destes apresentam zonas de inibição $\leq 5 \mathrm{~mm}$, pelo método direto e $60,8 \%$ pelo método deferido. Esses resultados sugerem que o crescimento de bactérias láticas na cana-de-açúcar não impossibilitará o desenvolvimento de G. diazotrophicus. 
ANEXOS 
ANEXO A - Bactérias láticas semeadas em meio agar MRS

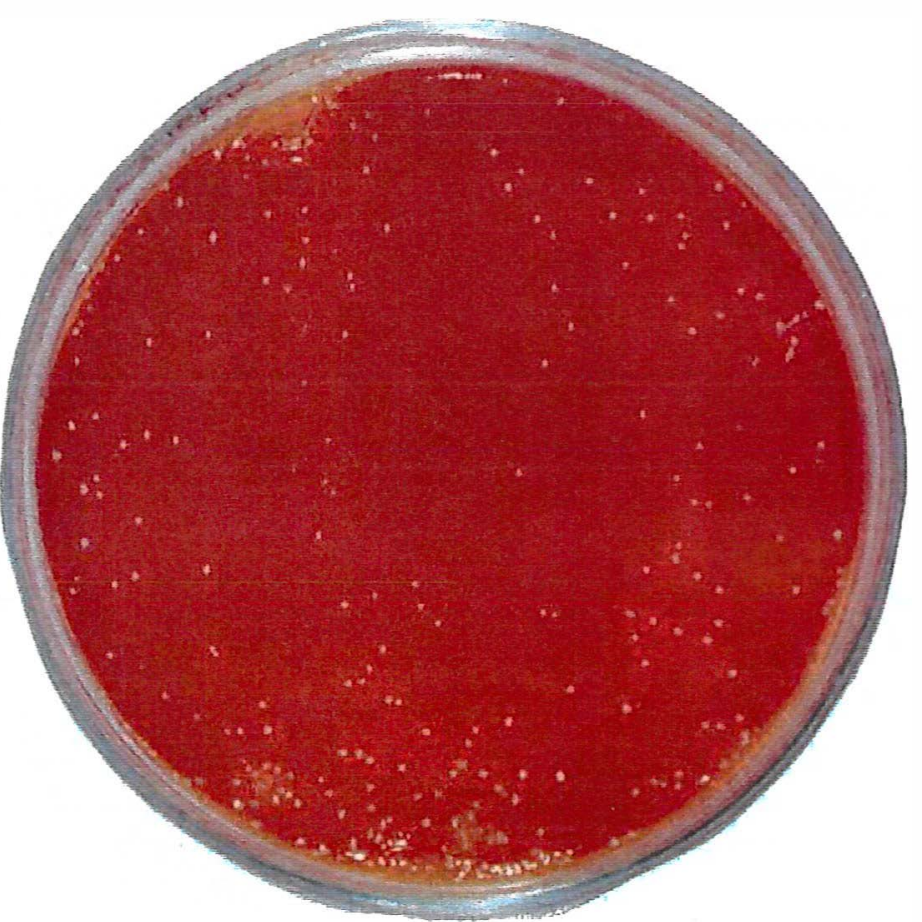

Foto 1 - Colônias típicas de bactérias láticas

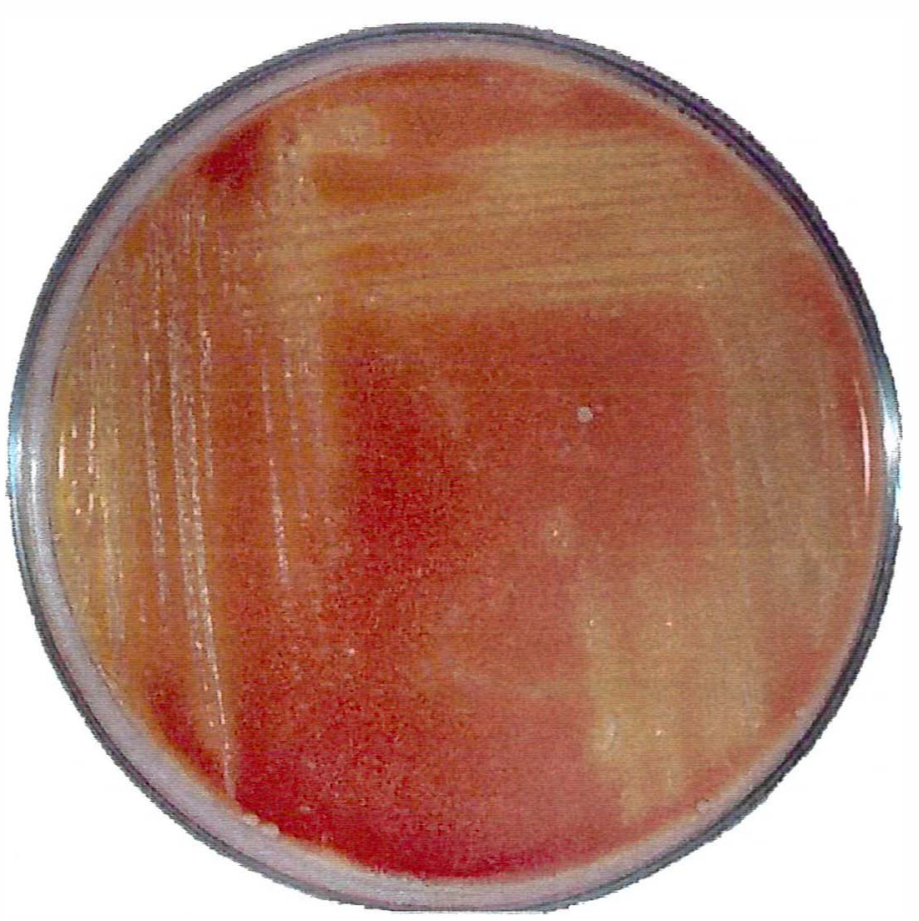

Foto 2- Isolado de bactéria lática 
ANEXO B - Bactérias láticas semeadas em meio D-MRS.

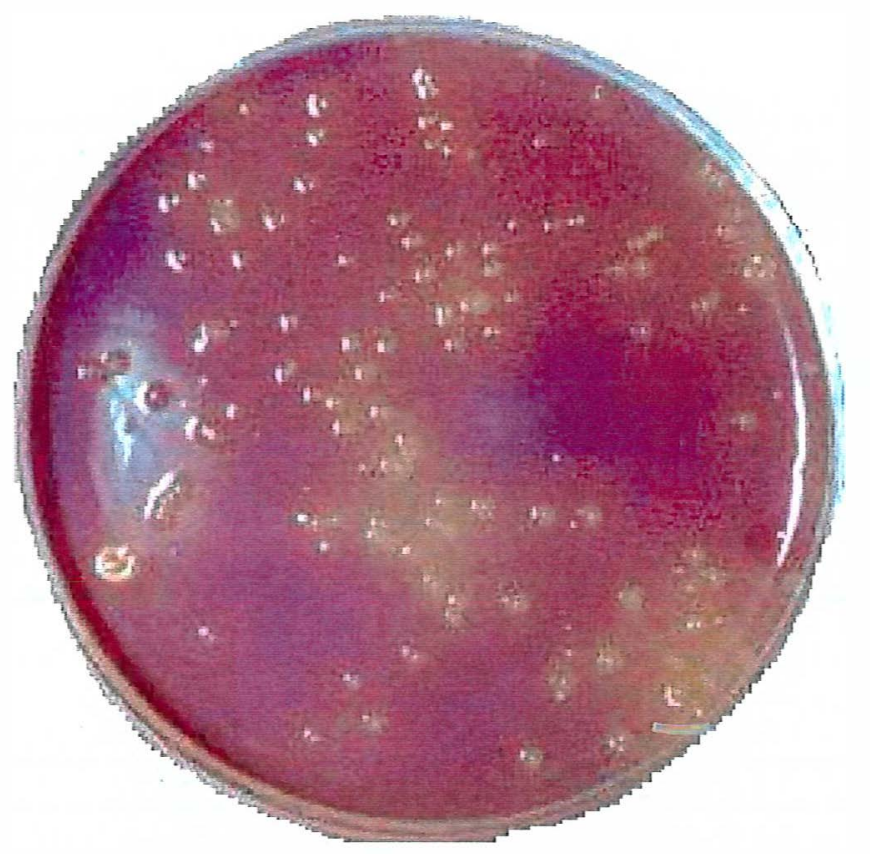

Foto 3 - Colônias típicas de bactérias láticas

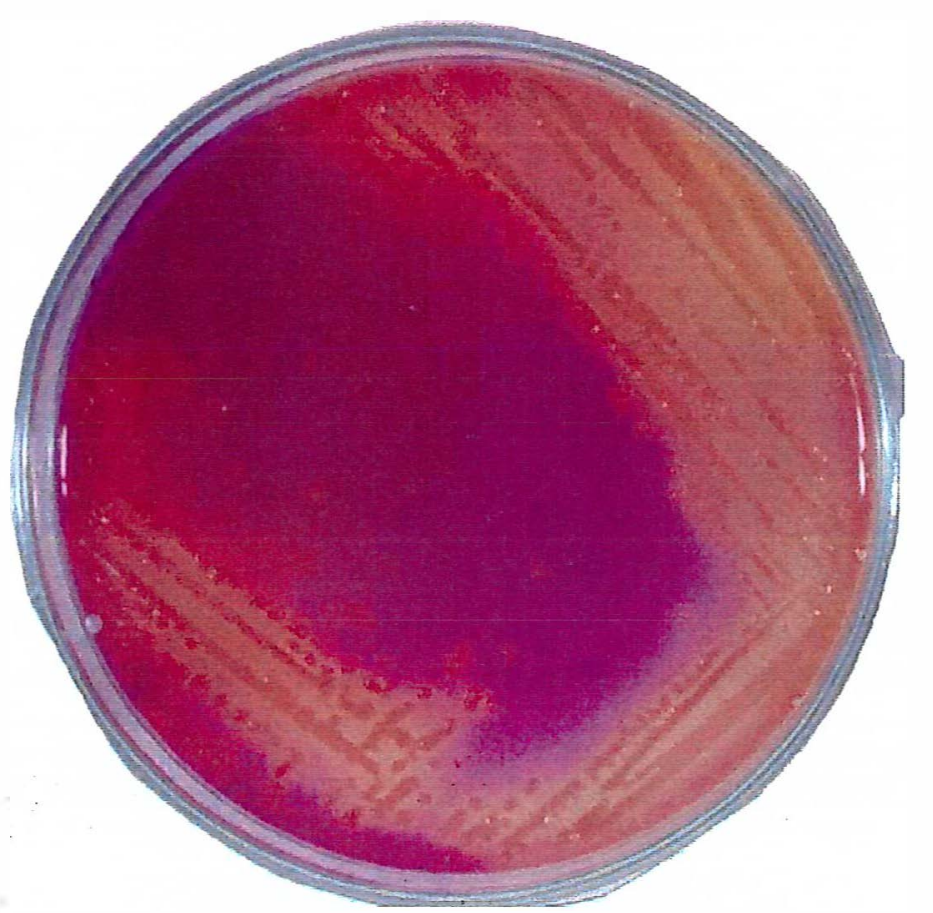

Foto 4 - Isolado de bactérias láticas 
ANEXO C - Bactérias láticas semeadas em agar $\mathrm{H}$.

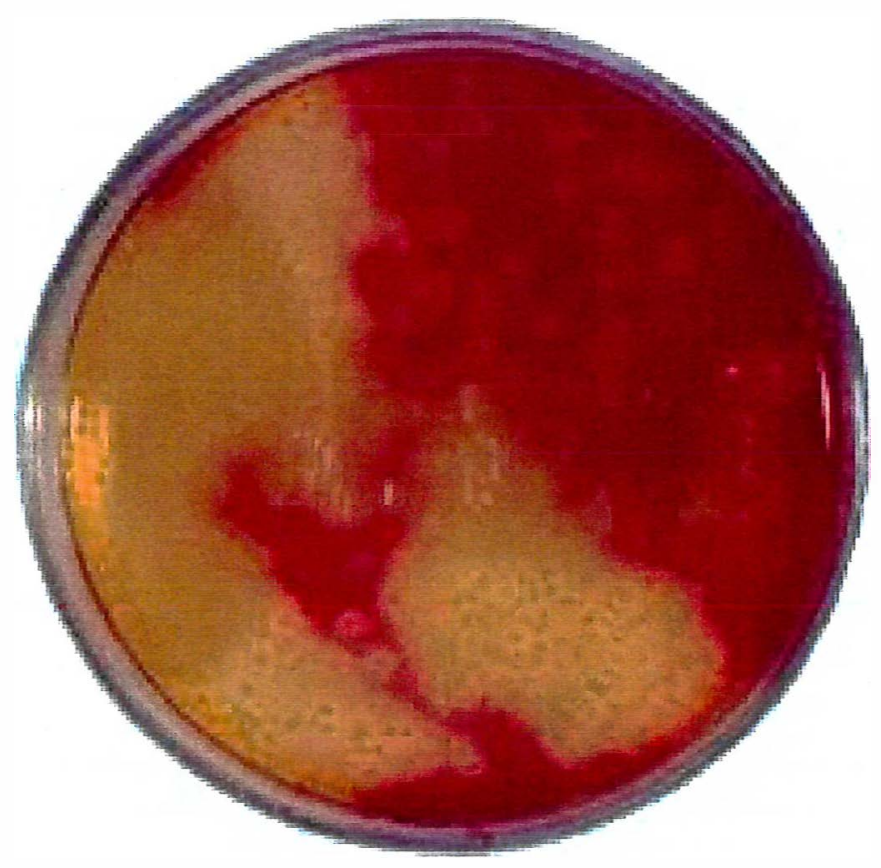

Foto 5 - Colônias típicas de bactérias láticas.

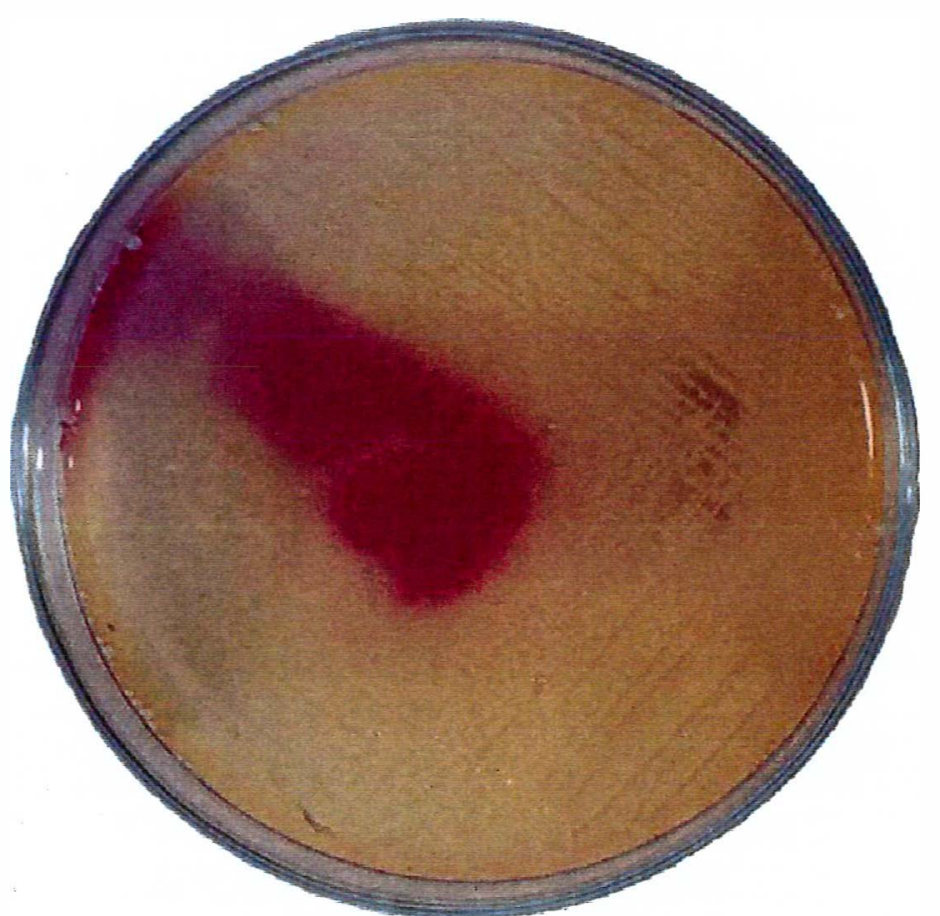

Foto 6- Isolado de bactérias láticas 
ANEXO D - Gluconacetobacter diazotrophicus semeado em agar SYP

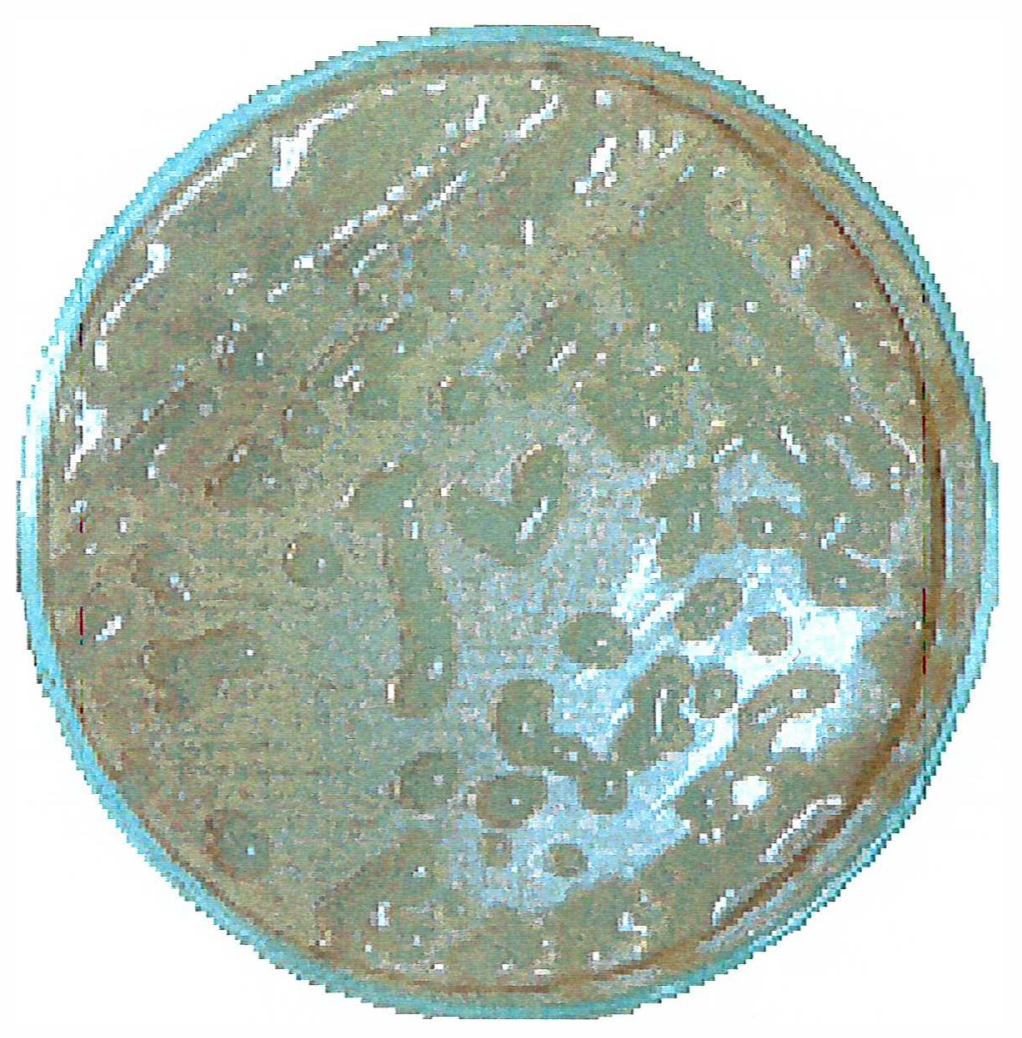

Foto 7 - Isolado de Gluconacetobacter diazotrophicus 
ANEXO E - Antagonismo de bactérias láticas

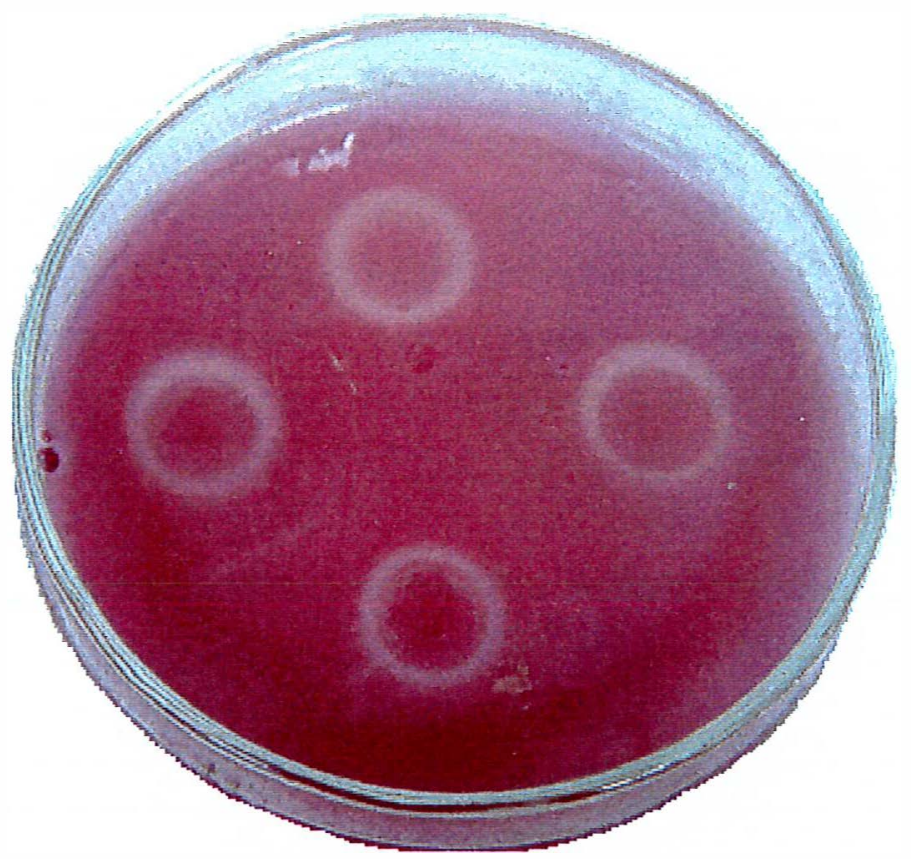

Foto 8 - Ausência de zonas de inibição

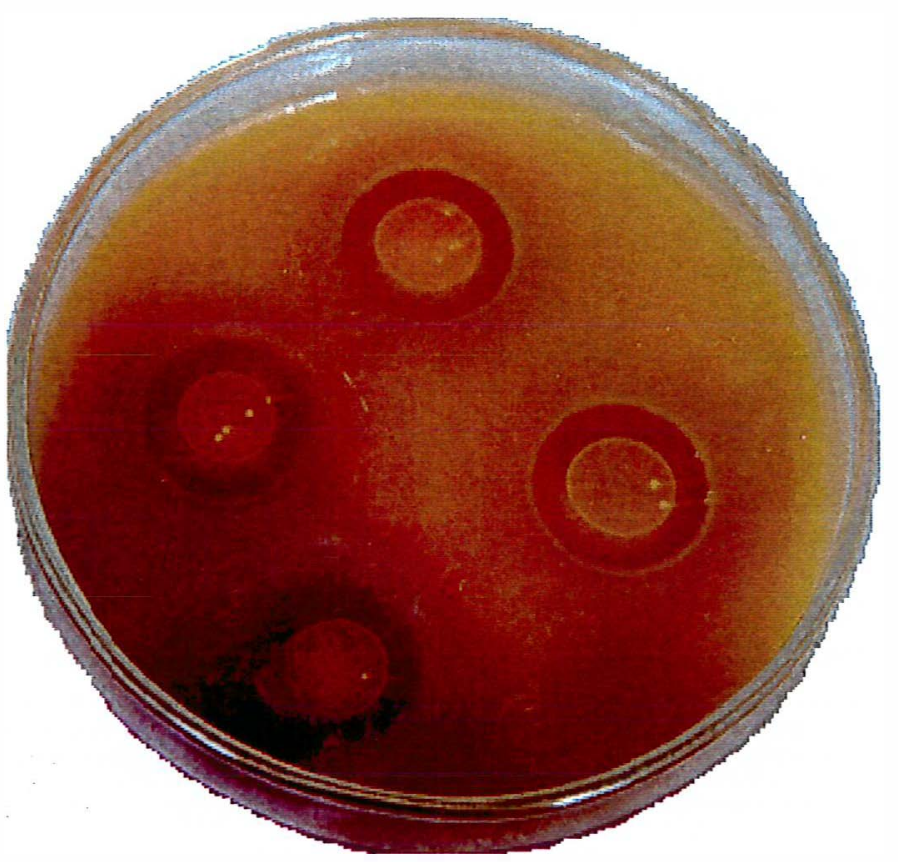

Foto 9 - Formação de zonas de inbição. 


\section{REFERÊNCIAS BIBLIOGRÁFICAS}

ADAMS, M.R. Fermented flesh foods. Progress in Industrial Microbiology, v.23, p.175-179, 1986.

ALAKOMI, H. -L.; SKYTTA, E.; SAARELA, M. et al. Lactic acid permeabilizes gram-negative bacteria by disruption the outer membrane. Applied and Environmental Microbiology, v.66, n.5, p.2001-2005, 2000.

ANGELOCCI, L.R.; NOVA, N.A.V.; PARRA, J.R.P. et al. Temperatura do colmo de cana-de-açúcar e sua relação com as condições meteorológicas na região de Piracicaba-SP. Revista Brasileira de Agrometeorologia, v.4, n.2, p.49-56. 1996.

AXELSSON, L.T.; CHUNG, T.C.; DOBNOGOSZ, W.J. et al. Production of a broad spectrum antimicrobial substance by Lactobacillus reuteri. Microbiology and Ecologycal Health and Disease, v.2, p.131-136, 1989.

BEVAN, D.; BOND, J. Micro-organisms in field and mill - a preliminary survey. In: CONFERENCE OF QUEENSLAND SOCIETY OF SUGAR CANE TECHNOLOGISTS, 38., 1971. Proceedings. p.137-143. 
BLAKEMAN, J.P.; FOKKEMA, N.J. Potential for biological control of plant diseases on the phylloplane. Annual Review of Phytopathology, v.20, p.167-192, 1982.

BODDEY, R.M.; OLIVEIRA, O.C.; URQUIAGA, S. et al. Biological nitrogen fxation associated with sugar cane and rice: contributions and prospects for improvement. Plant and Soil, v.174, n. 1/2, p.195-209, 1995.

BORCH, E.; MOLIN, G. Numerical taxonomy of psychrotrophic lactic acid bacteria from prepacked meat and meat products. Antonie van Leeuwenhoek, v.54, n.4, p.301-323, 1988.

CABALLERO-MELLADO, J.; MARTINEZ-ROMERO, E. Limited genetic diversity in the endophytic sugarcane bacterium Acetobacter diazotrophicus. Applied and Environmental Microbiology, v.60, n.5, p.1532-1537, 1994.

CAVALCANTE, V.A.; DÖBEREINER, J. A new acid-tolerant nitrogen fixing bacterium associated with sugar cane. Plant and Soil, v.108, p.23-31, 1988.

CHAVES, A.H. Isolamento de microrganismos da fermentação aromática e seu emprego na elaboração da manteiga. Viçosa, 1991. 79p. Dissertação (M.S.) Universidade Federal de Viçosa.

CLIVER, D.O.; MARTH, E.H. Preservation, sanitation, and microbiological specifications for food. In: Cliver, D.O. Foodborne diseases. San Diego: Academic Press, 1990. Cap.4, p.45-63. 
COJHO, E.H., REIS, V.M., SCHENBERG, A.C.G. et al. Interactions of Acetobacter diazotrophicus with amylolytic yeast in nitrogen-free bath culture. FEMS Microbiology Letters, v.106, p.341-346, 1993.

DAY, D.F. Spoilage in the sugar industry. In: WOOD, B.J.B. The lactic acid bacteria in health and disease. London: Elsevier Applied Science, 1992. v.1, p.343-361.

DÖBEREINER, J.; REIS, V.M.; LAZARINI, A.C. New $\mathrm{N}_{2}$-fixing bacteria in association with cereals and sugar cane. In: BOTHE, H.; De BRUJIN, F.J.; NEWTON, W.E. (Ed.) Nitrogen fixation: hundred years after. Stuttgard: Gustav Fischer, 1988. p.717-722.

DUNCAN, C.L.; COLMER, A.R. Coliforms associated with sugar cane plants and juices. Applied Microbiology, v.12, n.2, p.173-177, 1964.

EARNSHAW, R.G. The antimicrobial action of lactic acid bacteria: natural food preservation systems. In: WOOD, B.J.B. The lactic acid bacteria in health and disease. London: Elsevier Applied Science, 1992, v.1, p. 211-232.

EGAN, B.T. The infection process in sour storage rot. In: CONFERENCE OF THE QUEENSLAND SOCIETY OF SUGAR CANE TECHNOLOGISTS, 32., 1965. Proceedings. p.21-24.

FERREIRA, P.V. Estatística experimental aplicada à agronomia. 3.ed. Maceió: EDUFAL, 2000. 422p. 
FRANKE, I.H.; FEGAN, M.; HAYWARD, C. et al. Description of Gluconacetobacter sacchari sp nov., a new species of acetic acid bacterium isolated from the leaf sheath of sugar cane and from the pink sugar-cane mealy bug. International Journal of Systematic Bacteriology, v.49, n.4, p.1681-1693, 1999.

FUENTES-RAMIREZ, L.E.; JIMENEZ-SALGADO, T.; ABARCA-OCAMPO, I.R. et al. Acetobacter diazotrophicus, an indolacetic acid producing bacterium isolated from sugarcane cultivars of México. Plant and Soil, v.154, p.145-150, 1993.

GALLO, C.R., CANHOS, V.P., Contaminantes bacterianos na fermentação alcoólica - revisão. STAB. Açúcar, Álcool e Subprodutos, v.9, n.4/5, p.35$40,1991$.

GARVIE, E. I. Genus Pediococcus. In: SNEATH, P.H.A., MAIR, N.S., SHARPE, M.E. Bergey's manual of systematic bacteriology. 9.ed. Baltimore: Williams \& Wilkins, 1986. v. 2, p.1075-1079.

GERALDINI, A.M., DELAZARI, I., LEITÃO, M.F.F. et al. Caracterização de bactérias láticas em alimentos. I - avaliação de meios sólidos para contagens de culturas puras. Boletim do Instituto de Tecnologia de Alimentos, v.16, n.1, p.53-64, 1979. 
GILLIS, M.; KERSTERS, K.; HOSTE, B. et al. Acetobacter diazotrophicus sp. nov., a nitrogen-fixing acetic acid bacterium associated with sugar cane. International Journal of Systematic Bacteriology, v.39, p.361-364, 1989.

GIRAFFA, G.; GATTI, M., BELTRAME, A. Antimicrobial activity of lactic acid bacteria isolated from fermented meat products. Annual of Microbiology and Enzimology, v.44, p.29-34, 1994.

HAMDAM, I.Y.; MIKOLAJCIK, E.M. Acidolin: an antibiotic produced by Lactobacillus acidophilus. Journal of Antibiotics, v.27, n.8, p.631-636, 1974.

HAMMES, W.P., WEISS, N., HOLZAPFEL, W. The genera Lactobacillus and Carnobacterium. In: BALOWS, A., TRUPER, H.G., DWORKIN, M. et al. The prokaryotes. 2.ed. New York: Springer-Verlag, 1992. v.2, p.1535-1594.

HERRERO, M., MAYO, B., GONZÁLEZ, B. et al. Evaluation of technologically important traits in lactic acid bacteria isolated from spontaneous fermentations. Journal of Applied Bacteriology, v.81, n.5, p.565-570, 1996.

HOLLY, A. von; ClOETE, T.E.; HOLZAPFEL, W.H. Quantification and characterization of microbial populations associated with spoiled, vacuumpacked vienna sausages. Food Microbiology, v.8, n.2, p.95-104, 1991. 
HOLZAPFEL, W.H.; SCHILLINGER, U. The genus Leuconostoc. In: BALOWS, A., TRUPER, H.G., DWORKIN, M. et al. The prokaryotes. 2.ed. New York: Springer-Verlag, 1992. v.2, p.1508-1534.

JAMES, E.K.; REIS, V.M.; OLIVARES, F.L. et al. Infection of sugar cane by the nitrogen-fixing bacterium Acetobacter diazotrophicus. Journal of Experimental Botany, v.45, p.757-766, 1994.

JAY, J.M. Antimicrobial properties of diacetyl. Applied and Environmental Microbiology, v. 44, n.3, p.525-532, 1982.

KANDLER, O.; WEISS, M. Genus Lactobacillus. In: SNEATH, P.H.A.; MAIR, N.S.; SHARPE, M.E. Bergey's manual of systematic bacteriology. 9.ed. Baltimore: Williams \& Wilkins, 1986. v. 2, p.1209-1234.

KVASNIKOV, E.I.; KOVALENKO, N.H.; NESTERENKO, O.A. Lactic acid bacteria in nature and the national economy. Applied Biochemistry and Microbiology, v.18, p.665-676, 1983.

LEWUS, C.B.; KAISER, A.; MONTVILLE, T.J. Inhibition of foodborne bacterial pathogens by bacteriocins from lactic acid bacteria isolated from meat. Applied and Environmental Microbiology, v.57, n.6, p.1683-1688, 1991.

LI, R.; MacRAE, I.C. Specific association of diazotrophic Acetobacters with sugar cane. Soil Biology and Biochemistry, v.23, p.999-1002, 1991. 
LI, R.; MacRAE, I.C. Specific identification and enumeration of Acetobacter diazotrophicus in sugar cane. Soil Biology and Biochemistry, v.24, p.413419, 1992.

LIMA, E.; BODDEY, R.M.; DÖBEREINER, J. Quantification of biological nitrogen fixation associated with sugarcane using a ${ }^{15} \mathrm{~N}$ aided nitrogen balance. Soil Biology and Biochemistry, v. 19, n.2, p.165-170, 1987.

MACIEL, J.F. Atividade antibacteriana de culturas láticas isoladas de salame tipo italiano processado por fermentação natural. Viçosa, 1998. 52p. Dissertação (M.S.) - Universidade Federal de Viçosa.

MAZA, L.M.; PEZZLO, M.T.; BARON, E.J. Atlas de diagnóstico em microbiologia. Porto Alegre: Artmed, 1999. 216p.

McDONALDs, L.C.; FLEMING, H.P.; HASSAN, H.M. Acid tolerance of Leuconostoc mesenteroides and Lactobacillus plantarum. Applied and Environmental Microbiology, v.56, n.7, p.2120-2124, 1990.

MORISHITA, Y.; SHIROMIZU, K. Characterization of lactobacilli isolated from meats and meat products. International Journal of Food Microbiology, v.3, n.1, p.19-29, 1986.

NETTLES, C.G.; BAREFOOT, S.F. Biochemical and genetic characteristics of bacteriocins of food-associated lactic acid bacteria. Journal of Food Protection, v.56, n.4, p. 338-356, 1993. 
NOUT, M.J.R.; ROMBOUTS, F.M. Fermentative preservation of plant foods. Journal of Applied Bacteriology Symposium Supplement, v.73, p.13651475, 1992.

OVAES, F.V. Processos fermentativos. In: MUTTON, M.J.R. (ed.) Aguardente de cana - produção e qualidade. Jaboticabal: Funep, 1992. p.37-48.

OLIVEIRA, O.C.; URQUIAGA, S.; BODDEY, R.M. Buming cane: the longterm effects. International Sugar Journal, v.96, p.272-275, 1994.

OLSEN, A.; HALM, M.; JAKOBSEN, M. The antimicrobial activity of lactic acid bacteria from fermented maize (Kenkey) and their interactions during fermentation. Journal of Applied Bacteriology, v.79, n.5, p.506-512, 1995.

PAULA, M.A.; REIS, V.M.; DÖBEREINER, J. Interactions of Glomus clarum with Acetobacter diazotrophicus in infection of sweet potato (Ipomoea batatas) sugarcane (Saccharum spp.), and sweet sorghum (Sorghum vulgare). Biology and Fertility of Soils, v.11, p.111-115, 1991.

RACCACH, M.; McGRATH, R.; DAFTARIAN, H. Antibiosis of some lactic acid bacteria including Lactobacillus acidophilus toward Listeria monocytogenes. International Journal of Food Microbiology, v.9, p.25-32, 1989.

RAIJ, B.V. Fertilidade do solo e adubação. Piracicaba: Agronômica, 1991. 343p. 
REIS JÚNIOR, F.B.R.; SILVA, L.G.; REIS, V.M. et al. Ocorrência de bactérias diazotróficas em diferentes genótipos de cana-de-açúcar. Pesquisa Agropecuária Brasileira, v.35, n.5, p.985-994, 2000.

REIS, V.M.; ZANG, Y.; BURRIS, R.H. Regulation of nitrogenase activity by ammonium and oxygen in Acetobacter diazotrophicus. Anais da Academia Brasileira de Ciências, v.62, p.317, 1990.

REIS, V.M. Aspectos ecológicos e fisiológicos da bactéria fixadora de $\mathrm{N}_{2}$ Acetobacter diazotrophicus. Itaguaí, 1991. 119p. Dissertação (M.S.) Universidade Federal Rural do Rio de Janeiro.

REIS, V.M.; OLIVARES, F.L.; DÖBEREINER, J. Improved methodology for isolation of Acetobacter diazotrophicus and confirmation of its endophytic habitat. World Journal of Microbiology and Biotechnology, v.10, p.401405, 1994.

REITER, B.; HARNULV, G. Lactoperoxidase antibacterial system: natural occurrence biological functions and practical applications. Journal of Food Protection, v.47, n.9, p.724-732, 1984.

RIBEIRO, M.A. Aspectos da produção de peróxido de hidrogênio e inibição de bactérias por Lactobacillus acidophilus UFV H2b20. Viçosa, 1995. 60p. Dissertação (M.S.) - Universidade Federal de Viçosa. 
SCHILLINGER, U.; LUCKE, F.K. Antibacterial activity of Lactobacillus sake isolated from meat. Applied and Environmental Microbiology, v.55, n.8, p.1901-1906, 1989.

SILVA, N.; JUNQUEIRA, V.C.A.; SILVEIRA, N.F.A. Manual de métodos de análise microbiológica de alimentos. São Paulo: Varela, 1997. 295p.

SINGH, M. Estimation of nitrogen fixation in Saccharum spp. by $\mathrm{N}$ dilution method. Journal of Nuclear Agriculture and Biology, v.23, p.1-5, 1994.

STANIER, R.Y.; INGRAHAM, J.L.; WHEELIS, M.L. et al. The microbial world. 5.ed. New Jersey: Prentice-Hall, 1986. p.496-501.

STEPHAN, M.P.; OLIVEIRA, M.; TEIXEIRA, K.R.S. et al. Physiology and dinitrogen fixation of Acetobacter diazotrophicus. FEMS Microbiology Letters, v.77, p.67-72, 1991.

STIRLING, A.C.; WHITTENBURY, R. Sources of the lactic acid bacteria occurring in silage. Journal of Applied Bacteriology, v.26, p.86-90, 1963.

STUPIELLO, J.P.; FERNANDES, A.C. Qualidade da matéria-prima proveniente das colhedoras de cana picada e seus efeitos na fabricação de álcool e açúcar. STAB. Açúcar, Álcool e Subprodutos v.2, n.4, p.45-49, 1984. 
STUPIELLO, J.P. Produção de aguardente: qualidade da matéria-prima. In: MUTTON, M.J.R. (ed.) Aguardente de cana - produção e qualidade. Jaboticabal: Funep, 1992. p.37-48.

TANASUPAWAT, S.; EZAKI, T.; SUZUKI, K. et al. Characterization and identification of Lactobacillus pentosus and Lactobacillus plantarum strains from fermented foods in Thailand. Journal of General and Applied Microbiology, v.38, n.2, p.121-134, 1992.

TILBURY, R.H. Occurrence and effects of lactic acid bacteria in sugar industry. In: CARR, J.G.; CUTTING, C.V.; WHITING, G.C. (Ed.) Lactic acid bacteria in beverages and food. London: Academic Press, 1975. p.177-191.

TOMÉ JÚNIOR, J.B.T. Manual para interpretação de análise de solo. Guaíba: Agropecuária, 1997. 247p.

TORRIANI, S., DELLAGLIO, F., PALUMMERI, M. Characterization of lactobacilli isolated from italian salami. Annual Microbiology, v.40, p.225, 1990.

TORTORA, G.J.; FUNKE, B.R.; CASE, C.L. et al. Microbiologia. 6 ed. Porto Alegre: Artmed, 2000. 827p.

URQUIAGA, S.; CRUZ, K.H.S.; BODDEY, R.M. Contribution of nitrogen fixation to sugarcane: nitrogen 15 and nitrogen balance estimates. Soil Science Society of America Journal, v.56, p. 105-114, 1992. 
VISSER, R.; HOLZAPFEL, W.H.; BELZUIDENHOUT, J.J. et al. Antagonism of lactic acid bacteria against phytopathogenic bacteria. Applied and Environmental Microbiology, v.52, n.3, p.552-555, 1986.

VISSER, R.; HOLZAPFEL, W.H. Lactic acid bacteria in the control of plant pathogens. In: WOOD, B.J.B. The lactic acid bacteria in health and disease. London: Elsevier Applied Science, 1992. v.1, p. 211-232.

YAMADA, Y.; KONDO, K. Gluconoacetobacter a new subgenus comprising the acetate-oxidizing acetic acid bacteria with ubiquinone-10 in the genus Acetobacter. Journal of General and Applied Microbiology, v.30, n.4, p.297-303, 1984.

YAMADA, Y.; HOSHINO, K-.I.; ISHIKAWA, T. The phylogeny of acetic acid bacteria based on the partial sequences of $16 \mathrm{~S}$ ribosomal RNA: the elevation of subgenus Gluconoacetobacter to the generic level. Bioscience, Biotechnology and Biochemistry, v.61, p.1244-1251, 1997.

YAMADA, Y.; HOSHINO, K-.I.; ISHIKAWA, T. Gluconacetobacter nom. corrig. (Gluconoacetobacter [sic] ). In validation of publication of new names and new combinations previously effectively published outside the IJSB, List n.64. International Journal of Systematic Bacteriology, v.48, p.327-328, 1998. 